\title{
TRANSFORMATION OF LAKE ECOSYSTEM INTO PEAT BOG AND VEGETATION HISTORY BASED ON DURNE BAGNO MIRE (LUBLIN POLESIE, E POLAND)
}

\author{
KRYSTYNA BALAGA \\ Department of Physical Geography and Palaeogeography, Maria Curie-Sktodowska University, \\ Al. Kraśnicka 2cd, 20-718 Lublin, Poland
}

Received 17 October 2007

Accepted 8 November 2007

\begin{abstract}
In this paper, the history of Durne Bagno, i.e. the largest peat bog in the Lublin Polesie, is shown. Peat bogs are a unique element of the Polesie landscape. They occur mostly in the subregion of the Łęczna-Włodawa Lake District occupying 1.07\% of its area. They fill basin-shaped depressions without outflow, often in the immediate vicinity of dystrophic lakes. Based on interdisciplinary research, the changes of vegetation cover and the Durne Bagno lake-mire ecosystem in the Late Glacial and Holocene are presented. The environmental conditions are reconstructed from pollen analysis, detailed identification of algae of Pediastrum genus and chemical composition of deposits, together with the results of Cladocera analysis. The distribution of archaeological artefacts in the surroundings of Durne Bagno peat bog gives the view on the intensity of settlement in this area. The duration of the limnic and mire stages during the development of the ecosystem was different in different parts of the examined depression. In its central part the limnic stage lasted about 8000 years and included the period from the Late Glacial to the middle Holocene (to about $6000 \mathrm{BP}$ ). It is represented by 7 pollen zones and 6 chemical zones. The mire stage contained a part the Atlantic period and on the Subboreal and Subatlantic periods. It is represented by 4 pollen zones and 5 chemical zones. Limnic and mire deposits differ widely in the concentrations of chemical elements. The contents of mineral material and almost all analyzed elements in limnic deposits are high. These deposits are characterized by positive correlation between the contents of $\mathrm{Zn}$ and $\mathrm{Cr}$ and the frequency of Cladocera fauna. Peat contains very low amount of mineral material. The contents of $\mathrm{Ca}$, Sr and $\mathrm{Ba}$ are rather high in sedgemoss peat. The concentrations of these elements decrease upwards due to oligotrophic processes and sedentation of sedge-Eriophorum-Sphagnum peat. Peat succession was modified by pastoral economy of prehistoric man.
\end{abstract}

Keywords: pollen analysis, geochemistry, radiocarbon dating, peat bog, Lublin Polesie.

\section{INTRODUCTION}

Mires are one of most important landscape elements of the Lublin Polesie. They cover about $25 \%$ of its area. Most of them occur in the subregion of the LęcznaWłodawa Lake District where 410 mires are each over 1 ha in area and $28 \%$ of them are of lake origin (Borowiec, 1990 and Malicki and Litwińczuk, 2002). Fens are the most common type of mires in this subregion. Among them carbonate fens can be found. Transitional mires cover a considerably smaller area $(<2 \%)$ and

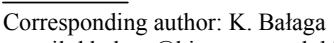

e-mail: kbalaga@biotop.umcs.lublin.pl

ISSN 1897-1695 (online), 1733-8387 (print) C 2007 GADAM Centre, Institute of Physics, Silesian University of Technology.

All rights reserved. usually occur near dystrophic lakes and in the marginal parts of peat bogs. They are overgrown by turf and mosssedge plants, which also form floating blankets of vegetation, the so-called "floating islands". Peat bogs cover only $1.07 \%$ of the area. They occur in basin-shaped depressions without outflow, often in the immediate surrounding of dystrophic lakes. The largest peat bog in the region is named Durne Bagno. Unfortunately, only few published papers concern this subject. The first pollen analysis of the deposits from the Durne Bagno peat bog was performed for Master's degree by S. Kyć at the Department of Plant Physiology of the Maria CurieSkłodowska University in the 1960's and the results, published by Paszewski and Fijałkowski (1971), included only tree curves. Therefore, new studies on geology and 
palaeoecology were undertaken. The results of geological investigations and studies of Cladocera development and also preliminary results of pollen analysis were published by Szeroczyńska (2003) and Bałaga et al. (2006). The aim of this paper is to present a synthesis of the problems concerning the changes of lake-mire ecosystem, history of vegetation cover and role of prehistoric man in its development. The basis was interdisciplinary palaeoecological research (pollen analysis, detailed identification of Pediastrum genus, analysis of chemical composition of deposits and Cladocera fauna) and study of prehistoric settlement in individual archaeological periods.

\section{SITE DESCRIPTION}

The Durne Bagno peat bog of continental type is located in the central part of the Polesie National Park. It occupies the clearly distinguishable oval-shaped depression in sandy deposits, about $1 \mathrm{~km}^{2}$ in area (Fig. 1). The western part of the depression is rather shallow and its eastern part reaches the depth of 7-8.5 $\mathrm{m}$ (Paszewski and Fijałkowski, 1971 and Bałaga et al., 2006). Limnic-mire deposits fill the depression. In the marginal belt (100$200 \mathrm{~m}$ ) of the peat bog only sedge-moss and Sphagnum peats occur, which overlie mineral substratum; their thickness reaches $2.5 \mathrm{~m}$. In the central, deeper part of the depression the thickness of typologically differentiated peat increases to 3-4.5 m.

Currently, the peat bog is overgrown by sparse pinebirch forest, with pine predominant in the central, highest part. The proportion of birch is higher in the marginal belt of the peat bog. The Ledo-Sphagnetum magellanici association forming "hummock and hollow" structure is composed of peat mosses (Sphagnum rubellum, Sph. magellanicum, Sph. cuspidatum, Sph. apiculatum and Sph. squarosum) with high proportion of dwarf shrubs of the Ericaceae family (Ledum palustre, Vaccinium uliginosum, $V$. vitis idaea, Oxycoccus quadripetalus, Andromeda polifolia and Calluna vulgaris). Brown mosses (Polytrichum strictum and Aulacomnium palustre) are also present (Paszewski and Fijałkowski, 1971). The marginal belt is also overgrown by willow shrubs with alder. In this zone Eriophorum vaginatum and E. latifolium are abundant. Trees were cut down in the selected parts of peat bog marginal zone in order to improve water conditions and to maintain "hummock and hollow" structure, which is typical of peat bogs. Dense birch saplings grow in this zone now.

From the south-west, north and north-east the peat bog is surrounded with varied forest. The communities of Alnetea glutinosae class predominate on peat soils occurring to the southern-west and northern-west of the peat bog and those of the Vaccinio-Piceetea and QuercoFagetea - on podzolic and brown soils to the north and east. Meadows occur to the south of the peat bog. The distribution of soils is presented in Fig. 2.

\section{MATERIALS AND METHODS}

Two deposit cores were taken from the deepest, central part of the depression: DB-1 (complete profile) and DB-2 (bottom layers). The core DB-3 (bottom layers)

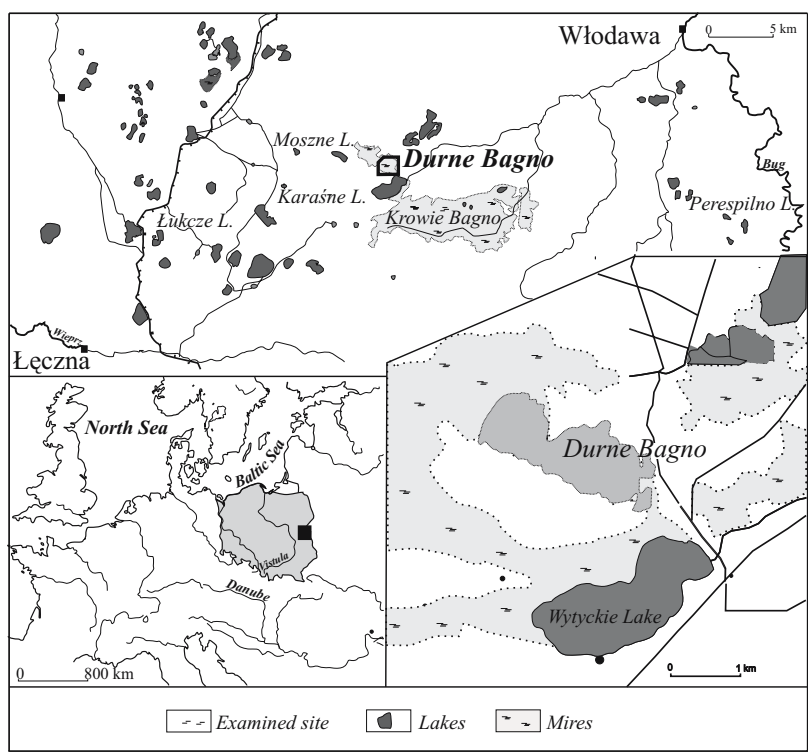

Fig. 1. Map of Łęczna-Włodawa Lake District. Location of the examined site.

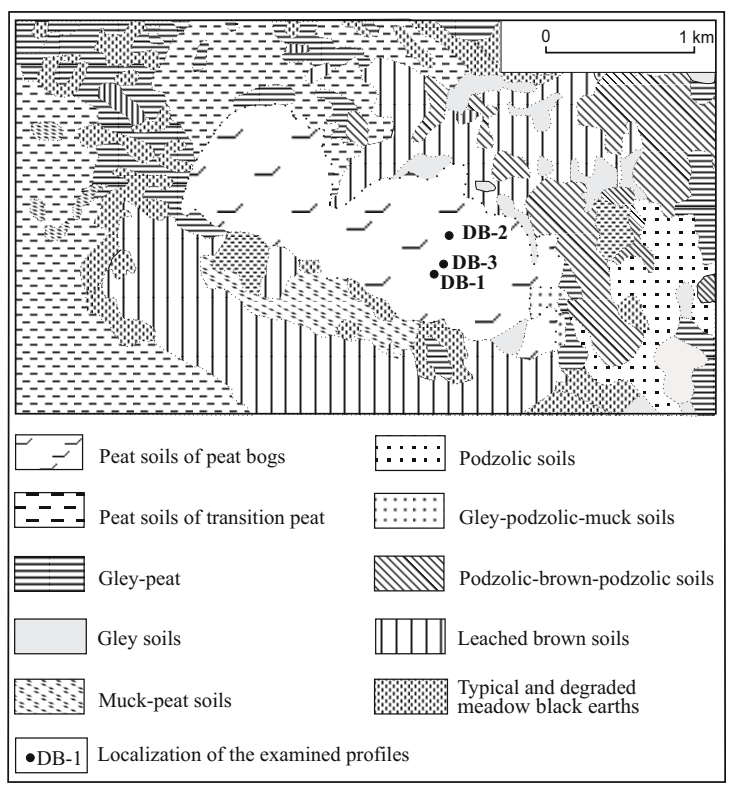

Fig. 2. Soils in the nearest vicinity of the Durne Bagno peat bog after Wicik and Piotrowski (2002) - modified. Location of the examined profiles.

was taken in the shallower part of the depression. The location of the examined profiles is shown in Figs 2 and 3.

\section{Pollen and macrofossils analysis}

For pollen analysis the samples of $1 \mathrm{~cm}^{3}$ volume were collected from three cores (DB-1, DB-2, DB-3). The deposits containing $\mathrm{CaCO}_{3}$ were treated with $\mathrm{HCl}$. Carbonate-free and peat deposits were preliminary treated with $10 \% \mathrm{KOH}$. The samples containing silica were treated with cold $40 \%$ HF. Then all samples were subjected to Erdtman's acetolysis (Faegri and Iversen, 1989). In order to calculate the concentration of sporomorphs, two tablets with Lycopodium spores were added to each 


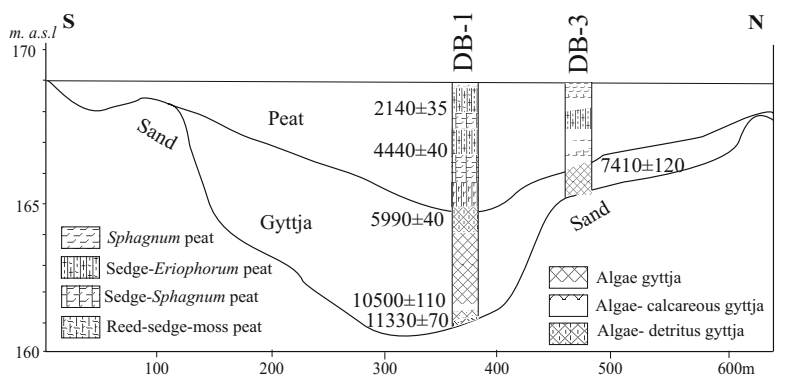

Fig. 3. Simplified geological cross-section of the Durne Bagno peat bog and radiocarbon dating results $(B P)$.

sample (Stockmarr, 1971). The macerated samples were sluiced with pure glycerine and stained with safranine. The calculations of pollen percentages and concentrations, pollen diagrams and statistical presentation of data were made basing on the POLPAL software. The percentage pollen diagrams were constructed using the sum of AP+NAP, without limnophyta, telmatophyta and spores.

Macrofossils of water plants were determined in the bottom part of the profile DB-1; deposit was washed according to the procedures of preparing material for radiocarbon dating by means of the AMS method.

\section{Chemical analyses}

The samples for chemical analyses were taken from the profile DB-1. The analyses were made in the Institute of Soil Science and Natural Environment Protection, Agricultural Academy in Lublin. The samples were dried to a constant weight and next mineralised in a wet state in a mixture of $\mathrm{HNO}_{3}$ and $\mathrm{HClO}_{4}(1: 1)$ in microwave ovens in an open system of Prolabo Microdigest 3.6. Major and minor elements were determined by means of emission spectrometry ICP on the Leeman Labs PS 950 apparatus. The content of mineral substances was determined by combustion at $550^{\circ} \mathrm{C}$ (in the Department of Physical Geography and Paleogeography, Maria CurieSkłodowska University in Lublin).

\section{Archaeological materials}

In order to interpret the impact of human economic activities on vegetation cover the archaeological data collected within a three-kilometre radius were presented as maps of findings from individual periods (Taras, 2005 and unpublished materials).

\section{Lithology}

Deposit cores were described according to the method by Troels-Smith in order to distinguish deposit components and to determine quantitatively their contents (Troels-Smith, 1955; Tables 1-3).

\section{Radiocarbon dating}

Five samples from the profile DB-1 were radiocarbon dated at the Radiocarbon Laboratory in Poznan and one sample from the core DB-2 - at the Radiocarbon Laboratory in Gliwice. Results of the radiocarbon dating are shown in Table 4 and Fig. 4.

\section{Pollen and geochemical records}

Pollen diagrams are divided into local pollen assemblage zones and subzones (LPAZ), i.e. biostratigraphic units characterized by their composition of sporomorphs (Berglund and Ralska-Jasiewiczowa, 1986). Unit boundaries are designated by means of traditional method taking into account the increase or decrease of the percentage curves of main trees and herbaceous plants and supported by means of Conslink numerical method (Walanus and Nalepka, 2003). Based on chemical composition of the

Table 1. Profile DB-1.

\begin{tabular}{|c|c|}
\hline $\begin{array}{l}\text { Depth } \\
(\mathrm{cm})\end{array}$ & Deposit description \\
\hline $0-30$ & $\begin{array}{l}\text { Sphagnum peat, not decomposed, light-yellow, } \\
\mathrm{Tb}^{0} 4, \mathrm{Th}+\text {, nig. } 1 \text {, sicc. } 2 \text {, elas. }+ \text {, strf. } 0 \text {, lim. } 0\end{array}$ \\
\hline $30-50$ & $\begin{array}{l}\text { Sphagnum-sedge peat, medium decomposed, light-brown, } \\
\mathrm{Th}^{2} 3, \mathrm{~Tb} 1 \text {, nig. } 2 \text {, sicc. } 2 \text {, elas. +, strf. } 0 \text {, lim. } 0\end{array}$ \\
\hline $50-100$ & $\begin{array}{l}\text { Sphagnum- sedge peat, medium decomposed, black-brown, } \\
\mathrm{Th}^{2} 3 \text {, Tb 1, DI (Ericaceae) +, nig. 3, sicc. 2, elas. +, strf. 0, lim. 0, }\end{array}$ \\
\hline $100-120$ & $\begin{array}{l}\text { Sedge-Eriophorum peat, slighty decomposed, black-brown, } \\
\mathrm{Th}^{2} 4, \mathrm{Ld}+, \mathrm{Tb}+\text {, nig. } 3 \text {, elas. }+ \text {, sicc. } 2 \text {, strf. } 0 \text {, lim. } 0\end{array}$ \\
\hline $120-150$ & $\begin{array}{l}\text { Sedge-Eriophorum peat, medium decomposed, black-brown, } \\
\mathrm{Th}^{2} 3, \mathrm{Ld}^{3} 1, \mathrm{~Tb}+\text {, nig. } 3 \text {, elas. }+ \text {, sicc. } 2 \text {, strf. } 0 \text {, lim. } 0\end{array}$ \\
\hline $150-168$ & $\begin{array}{l}\text { Sedge-Eriophorum peat, slighty decomposed, black-brown, } \\
T^{1} 14, \text { Ld +, nig. 3, elas. +, sicc. } 2 \text {, strf. } 0 \text {, lim. } 0\end{array}$ \\
\hline $168-260$ & $\begin{array}{l}\text { Sedge-Eriophorum peat, medium decomposed, black-brown, } \\
\mathrm{Th}^{2} 3, \mathrm{Ld}^{3} 1, \mathrm{~Tb}+\text {, nig. } 3 \text {, elas. }+ \text {, sicc. } 2 \text {, strf. } 0 \text {, lim. } 0\end{array}$ \\
\hline $260-265$ & $\begin{array}{l}\text { Sedge-Sphagnum peat, strongly decomposed, black-brown, } \\
\mathrm{Tb}^{3} 2 \text {, Ld }{ }^{3} 2 \text {, } \mathrm{Th}+\text {, nig. } 3 \text {, elas. }+ \text {, sicc. } 2 \text {, strf. } 0 \text {, lim. } 0\end{array}$ \\
\hline $265-360$ & $\begin{array}{l}\text { Sedge-Sphagnum peat, medium decomposed, black-brown, } \\
\mathrm{Tb}^{2} 3 \text {, Ld } 31 \text {, nig. } 3 \text {, elas. }+ \text {, sicc. } 2 \text {, strf. } 0 \text {, lim. } 0\end{array}$ \\
\hline $360-428$ & $\begin{array}{l}\text { Reed-Sphagnum-moss peat, slightly decomposed, black-brown, } \\
\mathrm{Tb}^{1} 3 \text {, Th2 } 1 \text {, Ld +, nig. 3, elas. 1, sicc. 2, strf. 0, lim. } 0\end{array}$ \\
\hline $428-510$ & $\begin{array}{l}\text { Algae-detritus gyttja, black-brown, } \\
\mathrm{Th}^{3} 2, \mathrm{Ld}^{3} 2 \text {, nig. } 3 \text {, elas. } 0 \text {, sicc. } 2 \text {, strf. } 0, \lim .0\end{array}$ \\
\hline $510-747$ & $\begin{array}{l}\text { Algae gyttja, black-brown, } \\
\operatorname{Ld}^{3} 4, T h+\text {, nig. } 3 \text {, elas. } 0 \text {, sicc. } 2 \text {, strf. } 0, \lim .0\end{array}$ \\
\hline $747-781$ & $\begin{array}{l}\text { Algae gyttja grey-brown, } \\
\mathrm{Ld}^{2} 4, \mathrm{Gs}+\text {, nig. } 2 \text {, elas. +, sicc. } 2 \text {, strf. +, lim. } 0\end{array}$ \\
\hline $781-789$ & $\begin{array}{l}\text { Algae gyttja grey-brown, with sand, } \\
\text { Ld23, Gs 1, nig. } 2.5 \text {, elas. }+ \text {, sicc. } 2 \text {, strf. +, lim. } 0\end{array}$ \\
\hline 789-794 & $\begin{array}{l}\text { Algae gyttja, grey-blue-brown, } \\
\mathrm{Ld}^{2} 4, \mathrm{Gs}+\text {, nig. } 2 \text {, elas. }+ \text {, sicc. } 2 \text {, strf. +, } \lim .0\end{array}$ \\
\hline $794-800$ & $\begin{array}{l}\text { Algae gyttja, grey-dark-brown, with sand, } \\
\mathrm{Ld}^{2} 2 \text {, Gs 2, nig. } 2.5 \text {, elas. +, sicc. } 2 \text {, strf. +, lim. } 0\end{array}$ \\
\hline
\end{tabular}

Table 2. Profile DB-2.

\begin{tabular}{cl}
\hline Depth (cm) & Deposit description \\
\hline $735-755$ & $\begin{array}{l}\text { Algae gyttja, olive green, with } \mathrm{CaCO}_{3}, \\
\text { Ld23, Lc 1, nig. 2, elas. +, sicc. 2, strf. +, lim. } 0\end{array}$ \\
\hline $755-770$ & Fine sand with silty interlayers \\
\hline
\end{tabular}

Table 3. Profile DB-3.

\begin{tabular}{cl}
\hline Depth (cm) & Deposit description \\
\hline \multirow{2}{2}{$265-270$} & $\begin{array}{l}\text { Sphagnum-sedge peat, light-brown, } \\
\mathrm{Th}^{2} 3, \mathrm{Ld} \mathrm{d}^{2} \text { 1, nig. 2, elas.1, sicc. 2, strf. 0, lim. } 0\end{array}$ \\
\hline $270-370$ & $\begin{array}{l}\text { Algae-carbonate gyttja, dark-grey, } \\
\text { Ld } d^{4} \text { 2, Lc 1, nig. 2, elas +, sicc. 2, strf. +, lim. } 0\end{array}$ \\
\hline $370-?$ & sand fine \\
\hline
\end{tabular}


examined deposits, eleven chemical zones are distinguished. The description of pollen and chemical zones is presented in Tables 5 and $\mathbf{6}$.

\section{REMARKS ABOUT STRATIGRAPHY}

Palynostratigraphy from the profile DB-1 indicates that bottom deposits are older than Alleröd. A similar age, pre-Alleröd (determined by palynological analysis) can be assigned to the bottom deposits in the profile DB-2. These results are inconsistent with the results of radiocarbon dating (AMS) for the profile DB-1 (Table 4 and Fig. 4). The sample from a depth of $795-793 \mathrm{~cm}$ was radiocarbon dated at $11330 \pm 70 \mathrm{BP}$ but pollen analysis indicates that the deposit was accumulated in an earlier, cold period. The sample from a depth of 744-742 cm, dated at $10500 \pm 110 \mathrm{BP}$, palynologically corresponds to the Alleröd. If we assume that radiocarbon ages are correct we should find that the deposits are disturbed; under the deposits of the Younger Dryas age (strongly confirmed by pollen analysis) deposits from both, the Alleröd and Younger Dryas, are present. Is it possible? Permafrost degradation and subsidence of substratum by the end of the Pleistocene (Bałaga et al., 2006 and Dobrowolski, 2006) did not provide stable conditions for the deposition of biogenic deposits. Even little hypsometric differentiation of the area could have favoured translocation of loose, usually waterlogged material. It could have been also caused by asymmetric arrangement of deposit layers in the lake. Such arrangement is related to wind action, especially in shallow parts of a lake during the initial phase of its formation (Tobolski, 2000). The occurrence of sloping deposit layers (oblique lamination) of the Alleröd age was found in some sections of the profiles examined in the Moszne and Karaśne sites. Similar oblique lamination occurs in some parts of the Durne Bagno profiles. Among 130 borings (Bałaga et al., 2006) at least 8 , situated mostly in the central and northern parts of the examined object, reveal oblique layers. However, more often they dip towards the $\mathrm{N}$ and $\mathrm{S}$ and not to the $\mathrm{W}$, as it could be expected from the prevailing wind directions (Warakomski, 1998). The role of wind in deposition of laminated deposits can also raise doubts.
The kind of the deposit sampled at 795-793 cm (mineral gyttja) and high NAP content $(40 \%)$ indicate that it was deposited under cold climatic conditions, so they were not deposited in the warm Alleröd. On the other hand, the decrease of the NAP values in the layer dated at $10500 \pm 110$ BP doesn't reflect cold climate of the Younger Dryas type suggesting its older age. Similar stratigraphic interpretation can be deduced from the occurrence of Hippophaë rhamnoides pollen. In most lakemire profiles of the Lęczna-Włodawa Lake District this pollen appears with the higher frequency in the deposits older than the Pinus-Betula zone, which is correlated with the Alleröd. Therefore, the lowest layers from the profiles DB-1 and DB-2 might be older than the Alleröd because they contain Hippophaë rhamnoides pollen (compare Krupiński et al., 2004). Based on the results of pollen analysis in the profiles DB-1 and DB-2, we cannot unequivocally settle the question whether the deposit is disturbed. The composition of pollen spectra from the bottom layers, which resembles that found in the Perespilno profile (well-dated by radiocarbon method, Goslar et al., 1999; Bałaga, 2004), can suggest the age of about 12000 BP.

Pollen analysis of the Holocene section (to 5990 BP) of the profile DB-1 also indicates disturbance in sedimentation; deposit discontinuity occurs in the Preboreal chronozone and at the turn of the Boreal and Atlantic chronozones. Such an interpretation is supported by the comparison of the pollen analysis results obtained for the profiles DB-1, DB-3 and nearby sites Moszne and Krowie Bagno (Bałaga et al., 1983, 1992 and Fig. 4). Compared with the profile DB-3, the section corresponding to the Preboreal chronozone in the profile DB-1 is reduced to the thickness of $25 \mathrm{~cm}$. The sedimentation hiatus at the turn of the Boreal and Atlantic chronozones in the profile DB-1 is evidenced by the relatively late (about 5990 BP) maxima of alder and oak. If sedimentation rate in the profile DB-1 is calculated for the section between the well-dated boundary YD/Holocene and $5990 \mathrm{BP}$, it is only about $0.03 \mathrm{~mm} /$ year. Such low result is inconsistent with the decreasing total pollen concentration. Total pollen concentration in the examined profile section evidences changeable accumulation of deposit -

Table 4. Radiocarbon ages of the Durne Bagno profiles. Atmospheric data from Reimer et al. (2004), OxCal v. 3.10 Bronk Ramsey (2001).

\begin{tabular}{|c|c|c|c|c|c|c|c|c|}
\hline \multirow[t]{2}{*}{ Lab. No } & \multirow{2}{*}{$\begin{array}{l}\text { Depth } \\
\text { (cm) }\end{array}$} & \multirow{2}{*}{$\begin{array}{c}{ }^{14} \mathrm{C} \text { Age } \\
\text { (BP) }\end{array}$} & \multicolumn{5}{|c|}{ Calendar age } & \multirow[t]{2}{*}{ Material } \\
\hline & & & \multicolumn{3}{|c|}{$68.2 \%$ confidence intervals } & \multicolumn{2}{|c|}{$95.4 \%$ confidence intervals } & \\
\hline \multirow[t]{2}{*}{ Poz-166 } & $142-144$ & $2140 \pm 35$ & $350 \mathrm{BC}$ & $(11.2 \%)$ & $320 \mathrm{BC}$ & $\begin{array}{ll}600 \mathrm{BC} & (18.9 \%)\end{array}$ & $290 \mathrm{BC}$ & peat/macrofossils \\
\hline & $(\mathrm{DB}-1)$ & & 210BC & $(57.0 \%)$ & 110BC & $240 \mathrm{BC} \quad(76.5 \%)$ & $50 \mathrm{BC}$ & \\
\hline \multirow[t]{3}{*}{ Poz-167 } & $270-272$ & $4440 \pm 40$ & $3260 \mathrm{BC}$ & $(3.4 \%)$ & $3240 \mathrm{BC}$ & 3330BC $\quad(17.9 \%)$ & $3220 B C$ & peat/macrofossils \\
\hline & (DB-1) & & $3100 B C$ & $(41.6 \%)$ & $3010 B C$ & $3180 B C$ & $3150 \mathrm{BC}$ & \\
\hline & & & $2990 \mathrm{BC}$ & $(23.2 \%)$ & $2920 \mathrm{BC}$ & 3120BC $(74.9 \%)$ & $2910 \mathrm{BC}$ & \\
\hline \multirow[t]{2}{*}{ Poz-168 } & $423-425$ & $5990 \pm 40$ & 4940BC & $(36.8 \%)$ & 4870BC & 4960BC $(93.25 \%)$ & $4770 \mathrm{BC}$ & peat/macrofossils \\
\hline & (DB-1) & & 4860BC & $(31.4 \%)$ & $4800 B C$ & 4760BC $(2.2 \%)$ & $4730 \mathrm{BC}$ & \\
\hline \multirow[t]{2}{*}{ Poz-1161 } & $742-744$ & $10500 \pm 110$ & 10900BC & $(64.5 \%)$ & 10350BC & 10950BC $\quad(95.4 \%)$ & $10000 \mathrm{BC}$ & macrofossils \\
\hline & $(\mathrm{DB}-1)$ & & 10300BC & $(3.7 \%)$ & 10200BC & & & \\
\hline \multirow[t]{2}{*}{ Poz-1187 } & $793-795$ & $11330 \pm 70$ & 11470BC & $(68.2 \%)$ & 11220BC & 11850BC $\quad(5.2 \%)$ & 11700BC & macrofossils \\
\hline & (DB-1) & & & & & $11550 \mathrm{BC} \quad(90.2 \%)$ & $11050 \mathrm{BC}$ & \\
\hline \multirow[t]{3}{*}{ Gd-10777 } & $265-275$ & $7410 \pm 120$ & $6400 \mathrm{BC}$ & $(57.3 \%)$ & $6200 \mathrm{BC}$ & 6460BC $(95.4 \%)$ & $6020 \mathrm{BC}$ & peat \\
\hline & (DB-3) & & 6190BC & $(5.0 \%)$ & $6160 \mathrm{BC}$ & & & \\
\hline & & & $6140 \mathrm{BC}$ & $(5.9 \%)$ & $6020 \mathrm{BC}$ & & & \\
\hline
\end{tabular}


Table 5. Description of pollen and chemical zones distinguished in the DB-1 profile.

\begin{tabular}{|c|c|c|c|}
\hline \multirow{2}{*}{\multicolumn{2}{|c|}{$\begin{array}{l}\text { LPAZ and LPAsubZ } \\
\text { (Depth, cm) }\end{array}$}} & \multicolumn{2}{|c|}{ Description of zones } \\
\hline & & \multirow{2}{*}{$\begin{array}{l}\text { pollen } \\
\text { Cyperaceae (up to } 38.6 \%) \text {, Betula nana }(3.4 \%) \text { and } \\
\text { Artemisia }(3.4-7.7 \%) \text { significant. Hippophaë and } \\
\text { Juniperus present. Limit: rise of Salix }\end{array}$} & \multirow{2}{*}{$\begin{array}{l}\text { chemical } \\
\text { 1. }(790-770 \mathrm{~cm}) \text {. The content of mineral material is high. } \\
\text { The } \mathrm{Ca} \text { content is variable. Ca is positively correlated with } \\
\text { other chemical elements excluding Fe, Mo, B, } \mathrm{P}, \mathrm{Zn}, \mathrm{Cd} \text {, } \\
\mathrm{Co} \text { and } \mathrm{Cr} \text {, which exhibit negative correlation }\end{array}$} \\
\hline \multirow{2}{*}{ 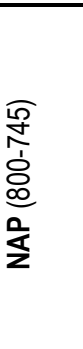 } & 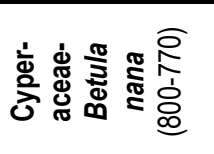 & & \\
\hline & 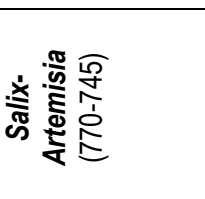 & $\begin{array}{l}\text { High Salix (8.1\%). Artemisia (up to } 5.2 \% \text { ), Cyper- } \\
\text { aceae (up to } 21 \% \text { ) and Poaceae (10.5\%) still pre- } \\
\text { dominate in NAP sum. Limit: decrease of NAP }\end{array}$ & \multirow[t]{2}{*}{$\begin{array}{l}\text { 2. }(770-720 \mathrm{~cm}) \text {. The content of mineral material progres- } \\
\text { sively decreases. The Ca content is high only in the older } \\
\text { part of the zone. The contents of elements, which are } \\
\text { negatively correlated with } \mathrm{Ca} \text {, increase in the younger } \\
\text { part. This zone is characterized by high concentrations of } \\
\mathrm{Sr} \text { and } \mathrm{Ba}\end{array}$} \\
\hline \multirow{2}{*}{\multicolumn{2}{|c|}{$\begin{array}{c}\text { Pinus-Betula } \\
(745-670)\end{array}$}} & \multirow{2}{*}{$\begin{array}{l}\text { Rise of Pinus (24-53.6\%) and Betula (24.7-51.8\%); } \\
\text { decrease of NAP, in it Artemisia to } 2.8 \% \text {. Typha } \\
\text { latifolia present. Limit: rise of NAP and Artemisia }\end{array}$} & \\
\hline & & & \multirow{2}{*}{$\begin{array}{l}\text { 3. }(720-650 \mathrm{~cm}) \text {. The content of mineral material is low. } \\
\text { The concentrations of Fe, Mn, Mo, B, P and Cd decrease } \\
\text { and those of } \mathrm{Zn}, \mathrm{Ni}, \mathrm{Cu}, \mathrm{Co} \text { and } \mathrm{Cr} \text { increase }\end{array}$} \\
\hline \multirow{2}{*}{\multicolumn{2}{|c|}{$\begin{array}{c}\text { Artemisia-Chenopodiaceae } \\
(670-555)\end{array}$}} & \multirow{2}{*}{$\begin{array}{l}\text { High NAP (17.8-29.3\%), in it Artemisia (7.3-12.1\%) } \\
\text { and Chenopodiaceae (1.1-2.3\%) significant. Junipe- } \\
\text { rus, Ephedra and Larix present. Limit: decrease of } \\
\text { NAP and Artemisia, rise of Ulmus and Corylus }\end{array}$} & \\
\hline & & & $\begin{array}{l}\text { 4. }(650-550 \mathrm{~cm}) \text {. The content of mineral material in- } \\
\text { creases. The } \mathrm{Ca} \text { content is still low and the concentra- } \\
\text { tions of } \mathrm{Mg}, \mathrm{K}, \mathrm{Na}, \mathrm{Al}, \mathrm{Ti}, \mathrm{V}, \mathrm{Cu}, \mathrm{Ni}, \mathrm{Co} \text { substantially } \\
\text { increase. In comparison with the older zones, the con- } \\
\text { tents of } \mathrm{Fe} \text { and } \mathrm{Mn} \text { tend to decrease }\end{array}$ \\
\hline \multicolumn{2}{|c|}{$\begin{array}{l}\text { Pinus-Ulmus } \\
(555-520)\end{array}$} & $\begin{array}{l}\text { Appearance and rise (up to } 3.2 \% \text { ) of Ulmus. Rise of } \\
\text { Corylus (up to } 2.2 \% \text { ), other tree taxa don't exceed } \\
1 \% \text {. Limit: rise of Corylus and Alnus }\end{array}$ & $\begin{array}{l}\text { 5. }(550-515 \mathrm{~cm}) \text {. The content of mineral material progres- } \\
\text { sively decreases. Mo, } \mathrm{Zn}, \mathrm{Cr} \text { and partially } \mathrm{P} \text { pass to the } \\
\text { group of elements positively correlated with } \mathrm{Ca}\end{array}$ \\
\hline \multicolumn{2}{|c|}{$\begin{array}{l}\text { Corylus } \\
(520-460)\end{array}$} & $\begin{array}{l}\text { High Corylus (9.6-13.8\%). Alnus (4.4-6.4\%), Fraxinus } \\
\text { (up to } 0.5 \% \text { ) and Quercus (1.0-2.2\%) present. Limit: } \\
\text { decrease of Corylus, rise of Alnus and Quercus }\end{array}$ & \multirow{2}{*}{$\begin{array}{l}\text { 6. }(515-415 \mathrm{~cm}) \text {. The content of mineral material still } \\
\text { decreases. The Ca content slightly rises in the younger } \\
\text { part of the zone. This zone is characterized by the in- } \\
\text { crease of Mo content }\end{array}$} \\
\hline \multirow{6}{*}{ 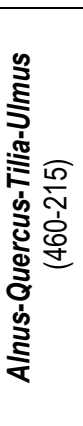 } & \multirow{2}{*}{$\begin{array}{c}\text { Alnus } \\
(460-370)\end{array}$} & \multirow{2}{*}{$\begin{array}{l}\text { High Alnus (16.0-23.9\%). Decreasing Corylus (to } \\
6.4 \%) \text {, increasing Quercus, Tilia and Fraxinus. Vis- } \\
\text { cum present. Limit: decrease of Alnus }\end{array}$} & \\
\hline & & & \multirow{4}{*}{$\begin{array}{l}\text { 7. }(415-335 \mathrm{~cm}) \text {. The content of mineral material de- } \\
\text { creases to the minimum values. } \mathrm{Mg}, \mathrm{K}, \mathrm{Al} \text {, Fe and } \mathrm{Mn} \text { are } \\
\text { positively correlated with this fall. The concentrations of } \\
\mathrm{Ca}, \mathrm{Sr} \text { and } \mathrm{Ba} \text { increase } \\
\begin{array}{l}\text { 8. }(335-235 \mathrm{~cm}) \text {. The contents of } \mathrm{Ca}, \mathrm{Sr} \text { and Ba progres- } \\
\text { sively decrease and the } \mathrm{P} \text { content increases }\end{array}\end{array}$} \\
\hline & \multirow[t]{2}{*}{$\begin{array}{l}\text { Quercus } \\
(370-305)\end{array}$} & \multirow{2}{*}{$\begin{array}{l}\text { Rise of Quercus }(7.2-14.3 \%) \text {, Ulmus (up to } 7.3 \%) \text {, } \\
\text { Corylus ( } 9.9-16.5 \%) \text { and Tilia (0.5-2.2\%). Continuous } \\
\text { but low curve of Carpinus. Hedera helix appears. } \\
\text { Limit: decrease of Ulmus to } 3.1 \%\end{array}$} & \\
\hline & & & \\
\hline & \multirow[t]{2}{*}{$\begin{array}{c}\text { Alnus-Corylus } \\
(305-215)\end{array}$} & \multirow{2}{*}{$\begin{array}{l}\text { High Alnus (up to } 25.7 \% \text { ) and Quercus (up to } 13 \% \text { ). } \\
\text { Rise of Corylus (up to } 21.9 \% \text { ). First pollen grain of } \\
\text { Cerealia appears and Artemisia increases. Rising } \\
\text { Sphagnum.Limit: rise of Carpinus (up to } 3.2 \% \text { ) }\end{array}$} & \\
\hline & & & $\begin{array}{l}\text { 9. }(235-165 \mathrm{~cm}) \text {. The concentrations of } \mathrm{Ca}, \mathrm{Sr} \text { and } \mathrm{Ba} \text { still } \\
\text { decrease and the content of mineral material remains low }\end{array}$ \\
\hline \multirow{5}{*}{ 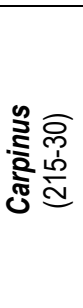 } & \multirow{2}{*}{$\begin{array}{r}\text { Pinus-Betula } \\
(215-115)\end{array}$} & \multirow{2}{*}{$\begin{array}{l}\text { Rising Alnus (9.3-31.6\%), Quercus (5.7-15.1\%) and } \\
\text { Carpinus (3.2-9.3\%). Limit: rise of Alnus }\end{array}$} & \multirow{3}{*}{$\begin{array}{l}\text { 10. }(165-75 \mathrm{~cm}) \text {. The contents of } \mathrm{Fe} \text { and } \mathrm{Mn} \text { decrease to } \\
\text { the minimum values. The contents of } \mathrm{Pb} \text { and periodically } \\
\text { also of mineral material, slightly rise }\end{array}$} \\
\hline & & & \\
\hline & & $9 \%)$ and Pinu & \\
\hline & (115-45) & Limit: r & $\begin{array}{l}\text { 11. }(75-15 \mathrm{~cm}) \text {. The content of mineral material increases } \\
\text { and the concentrations of } \mathrm{Ca}, \mathrm{Fe} \text { and } \mathrm{Mn} \text { are minimum. }\end{array}$ \\
\hline & $\begin{array}{c}\text { NAP } \\
(45-30)\end{array}$ & High NAP (24.5-41.8\%), in it human indicators & $\begin{array}{l}\text { The zone is characterized by the increase of the contents } \\
\text { of } \mathrm{Pb}, \mathrm{Cu} \text { and } \mathrm{Cd} \text { and periodically also } \mathrm{Cr} \text { and } \mathrm{P}\end{array}$ \\
\hline
\end{tabular}

Table 6. Description of pollen zones distinguished in the DB-2 and DB-3 profiles.

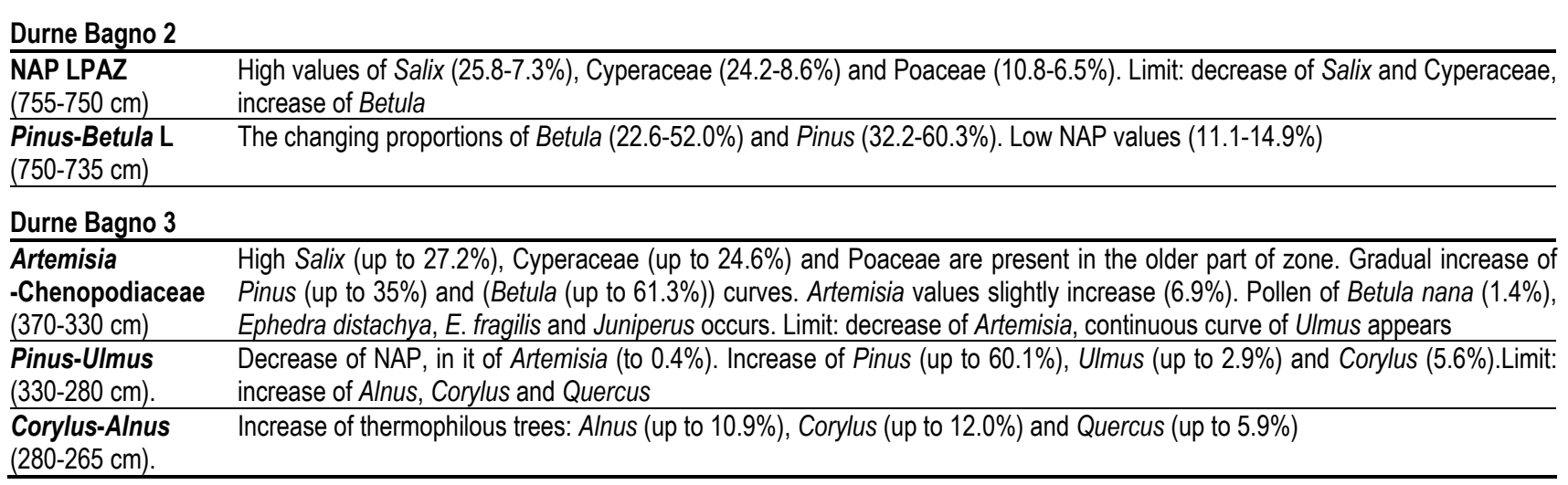


rather rapid in the initial phase and consistently decreasing till about 6000 BP. Therefore, the weakly recorded Preboreal chronozone is not taken into consideration and the maximum of hazel (well-dated at $8800 \mathrm{BP}$ in the Moszne profile, Bałaga et al., 1992) is used in further calculations of sedimentation rate. Assuming continuous accumulation, the average sedimentation rate between the hazel maximum and the layer dated at $5990 \mathrm{BP}$ is about $0.3 \mathrm{~mm} /$ year. However, the results of pollen analysis indicate a probable sedimentation hiatus between the Boreal and Atlantic chronozones so the age of the determined pollen boundaries between them is only approximate.

\section{CHANGES OF VEGETATION COVER AROUND THE EXAMINED PEAT BOG}

Development of the vegetation in the Durne Bagno area has been characterized on the basis of LPAZ distinguished in the profiles: DB-1 (Figs 5a and 5b), DB-2 (Fig. 6), DB-3 (Fig. 7). Based on the available radiocarbon dating, they are correlated with chronozones in accordance with the proposal of Mangerud et al. (1974).

\section{Late Glacial}

The development of vegetation cover in the Late Glacial was recorded by three pollen zones and two subzones

\section{NAP LPAZ (DB-1; 800-745 cm, DB-2; 755-750cm)}

The zone with the high values of NAP corresponds to the Older Dryas chronozone. The results of radiocarbon dating from this section are inconsistent with indirect dating based on palynological analysis (see chapter "Remarks about stratigraphy"). Taking into account the welldated initial layer of lacustrine sedimentation in the Lake Perespilno (Goslar et al., 1999 and Bałaga 2004) with the similar pollen composition, we can suppose that this zone represents even older deposits from the end of the Pleniglacial. Such a conclusion is also confirmed by the results of radiocarbon dating of bottom layers of lacustrine deposits (older than 12,300 BP) obtained for other lakes of the Lęczna-Włodawa Lake District (see Bałaga, 2007). Two distinguished subzones (DB-1) indicate the differentiated succession of communities.

- Cyperaceae-Betula nana subzone (DB-1; 800$770 \mathrm{~cm}$ )

The low total pollen concentration (Fig. 4) and high pollen percentages of NAP evidence woodless landscape. The communities of herbaceous plants and shrubs developed on habitats of various soil-moisture. Tundra with dwarf Betula nana and Salix (cf. polaris) occurred on wet habitats around a lake, which was forming at that time. The communities of grasses-Artemisia steppe spread on dry habitats on the surrounding elevations. At the wet shores of the shallow lake the communities of herbs with Cyperaceae, Equisetum, Musci and ferns grew. The presence of Betula nana indicates that the temperature of the coldest month was below $0^{\circ} \mathrm{C}$ (Tobolski, 1991; Granoszewski 1998).

- Salix-Artemisia subzone (DB-1;770-745 cm)

The rise of Betula pollen evidences the progressive expansion of open birch forests because of gradual cli-

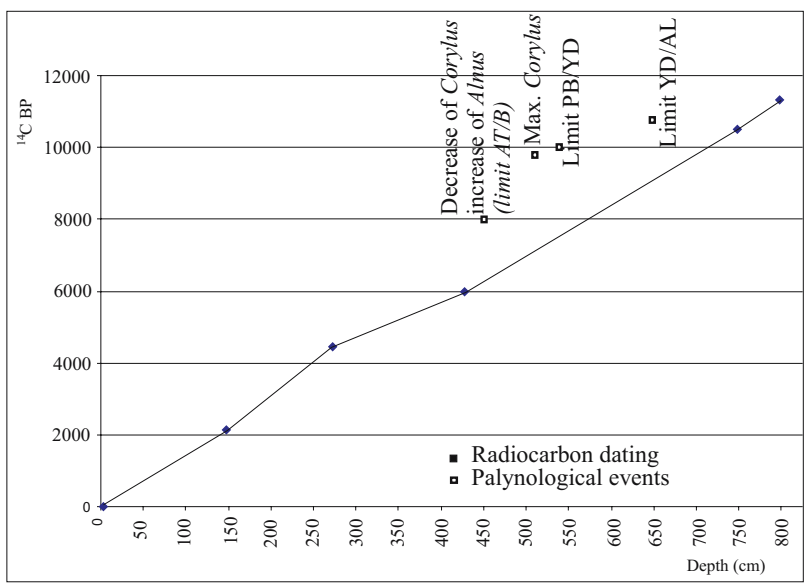

Fig. $4 .{ }^{14} \mathrm{C}$ conventional age of dated samples in relation of their depth for the profile DB-1 compared with palynological events.

mate warming. The communities of herbaceous plants became enriched with new taxa. The decreasing curve of Cyperaceae and increasing pollen values of vegetation representing dry habitats with Poaceae and Artemisia can be related with less humid climate at that time. The presence of pollen of Betula nana indicates the continuing existence of patches of tundra communities. The wet habitats were favourable for willows development, where their thickets increasingly became dense. Sporadically appearing pollen of Alnus viridis was produced by shrubs, which probably occupied slightly moist mineral soils near the lake. Potamogeton sec. Eupotamogeton and Myriophyllum spicatum appeared in the lake and algae of Pediastrum genus were abundant. Musci, ferns and horsetails had good conditions and continued their development in the belt around the lake.

\section{Pinus-Betula LPAZ (DB-1; 745-670 cm, DB-2; 750- $735 \mathrm{~cm}$ )}

This pollen zone represents the Alleröd chronozone. The rise in total pollen concentration indicates more intensive development of vegetation cover. The response to the amelioration of climatic conditions was the development of open birch and pine forests. The expansion of pine at the expense of birch occurred in the middle phase of this chronozone. Birch reaches the maximum pollen values $(51.8 \%)$ in the first and the final phase of the zone. The development of birch forests, preceded by the first decrease in NAP, is a typical feature of the Polesie area, recorded in many pollen diagrams. The deposit layer with the maximum values of Betula pollen has various thicknesses; the greatest was found in the profiles Łukcze II and III, Krowie Bagno and in the laminated sequence from Lake Perespilno. Birch zone in these profiles is related to the Bölling or Meiendorf interstadial warming (Bałaga et al., 1983; Bałaga, 1991, 2004 and RalskaJasiewiczowa et al., 1999). The mentioned first high percentage of Betula pollen in the profile DB-1 (depth of $740 \mathrm{~cm}$ ) is not clearly marked in the concentration diagram (Fig. 5a). Significant rise in the concentration of Betula pollen occurs a bit higher, together with that of Pinus (depth of $720 \mathrm{~cm}$ ). This simultaneous rise in concentrations can be related to a low sedimentation rate, so 


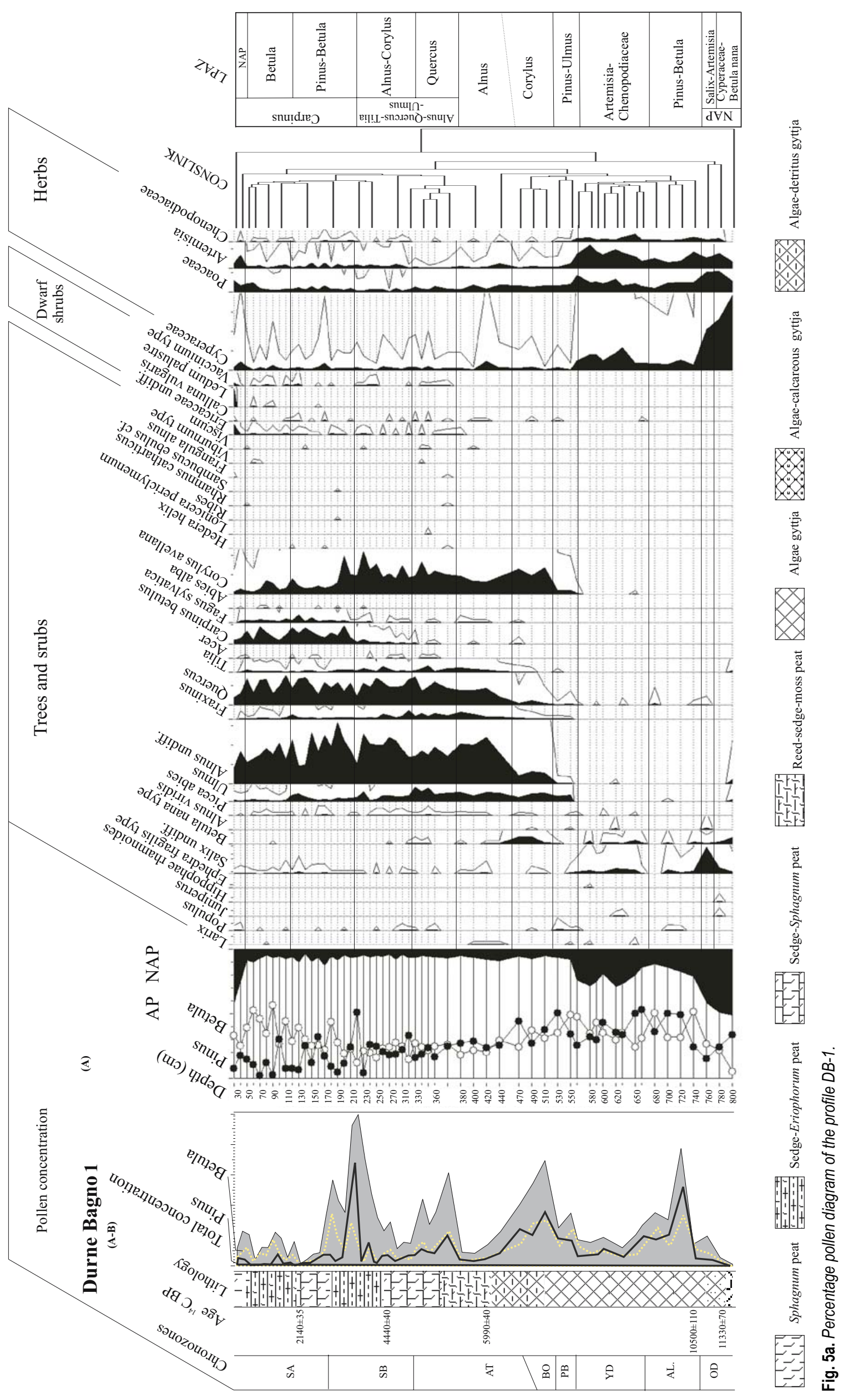




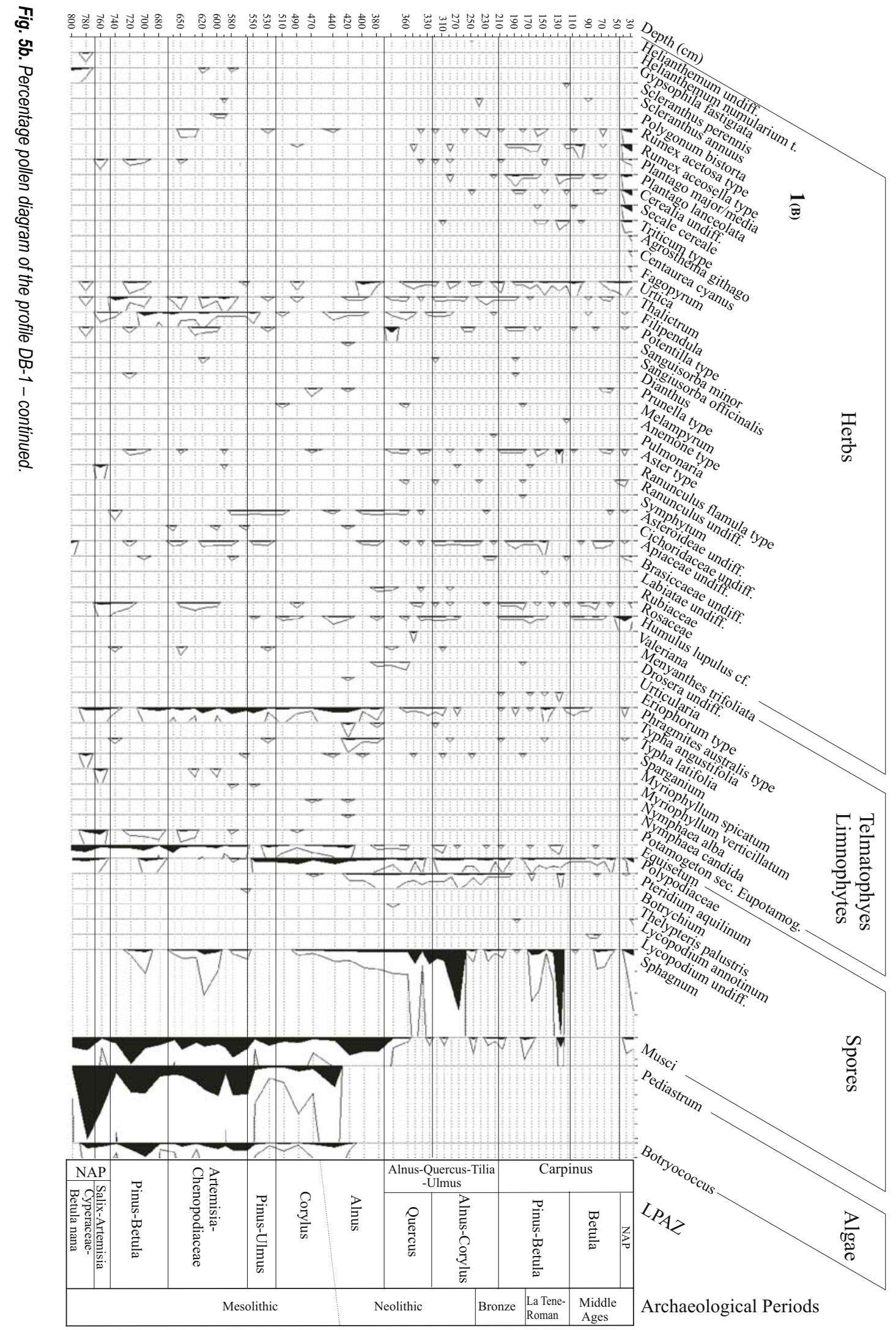

it can indirectly indicate a weakly developed birch phase on this site.

Single pollen grains of Populus may indicate its presence in these forests. Aspen is a non-demanding tree that belongs to the earliest colonizers of the areas. On wet habitats around the lake the favourable conditions for the development of both willow thicket as well as patches of tundra plants with Betula nana still persisted, although they were not as abundant as before. The development forests impeded the expansion of open vegetation as evidenced by the decrease on NAP. In the reduced open spaces the communities of herbaceous plants growing on 


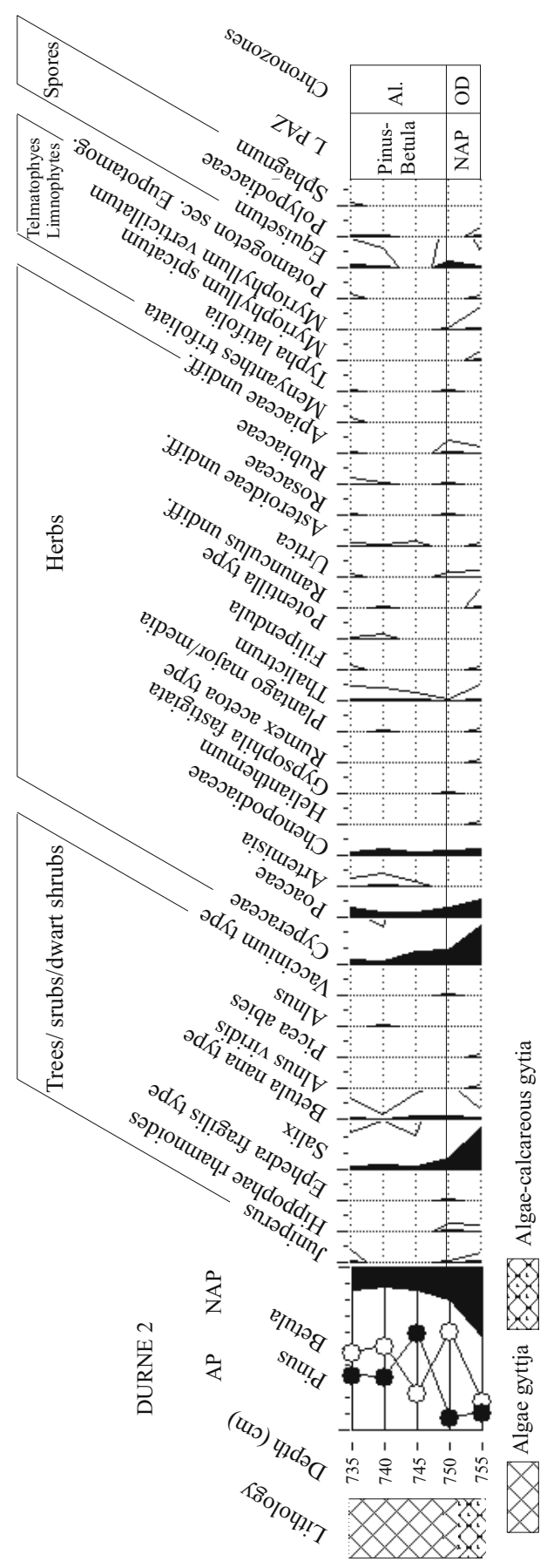

Fig. 6. Percentage pollen diagram of the profile DB-2.

various habitats still had good conditions for their development. On the wet habitats there were favourable conditions for occurrence of herbaceous plants including Thalictrum, Filipendula, Equisetum and Urtica. On the shores around the lake stands of Cyperaceae, Typha latifolia, Phragmites australis and Menyanthes trifoliata formed part of reedswamp belt. Potamogeton sect. Eupotamogeton still existed in the lake and the colonies of Pediastrum developed, though they were more abundant in the older phase of this zone. The occurrence of Typha latifolia indicates that the mean temperature of July was not lower than $14-15^{\circ} \mathrm{C}$.

\section{Artemisia-Chenopodiaceae LPAZ (DB-1; 670-555 cm, $D B-3 ; 375-330 \mathrm{~cm}$ )}

This zone corresponds to the Younger Dryas chronozone. Climate cooling in the Younger Dryas caused the gradual opening of landscape as is clearly indicated by low total pollen concentration (Fig. 5a). Vegetation of park type with Pinus and Betula developed and lightdemanding herbaceous plants and shrubs dominated again. Single pollen grains of Larix, which are not adapted to long transport, can indicate that this tree occurred in the surrounding area. On wet habitats around the lake the both willow thickets as well as patches of tundra plants with Betula nana developed. Alnus viridis probably occurred on mineral soils because its pollen is sporadically found again. On the dry habitats there were favourable conditions for the occurrence of herbaceous plants including Artemisia, Chenopodiaceae, Gypsophila fastigata and Helianthemum sp. The relatively high Artemisia pollen percentages (12.1\%) indicate that steppe-like vegetation occurred close to Durne Bagno. Heliophilous shrubs of Juniperus communis, Ephedra fragilis, E. distachya and Hippophaë rhamnoides were present in these communities. Artemisia steppe vegetation predominates in climates characterized by very cold winters, intensive winter precipitation and summer drought (Prentice et al, 1992 and Vierling, 1998). Myriophyllum spicatum occurred in the lake and algae of Pediastrum genus developed plentifully but thermophilous species, such as Typha latifolia, disappeared.

\section{Holocene}

The development of vegetation cover in the Holocene was recorded in four pollen zones and six subzones.

\section{Pinus-Ulmus LPAZ (DB-1; 555-520 cm, DB-2; 335- $305 \mathrm{~cm}$ )}

This zone is correlated with the Preboreal chronozone. The comparison of the two profiles suggests that only a small part of this chronozone is represented in the profile DB-1. Pollen spectra from the profile DB-2 provide more complete picture. They reflect the progressive development of birch-pine forests (with predominant birch up to $52.8 \%$ in profile DB-2) in the study area. A component within these forests was elm. Ulmus pollen consistently appears as the earliest of all the deciduous tree pollen (Bałaga et al., 1983, 1991 and Bałaga 1991, 2004). Its early occurrence was probably connected with its migration from the south-east (Zachowicz et al., 2004). Hazel spread into these areas and its significant development started at the end of this chronozone. The occurrence of Populus pollen was probably connected with the development of communities resembling modern wetland Salici-Populetum forests. The sustained curve of Betula nana pollen indicated that patches of tundra communities were still developing on wet habitats too. Still low pollen values of mesophilous deciduous trees indicate that their role in the forests was still unimportant. Forests were overgrowing large areas, limiting the areas occupied until then by light-demanding herbaceous plants such as Artemisia and Chenopodiaceae. Along wet edges of forests the tall-herbs communities were growing, among them Filipendula and Humulus. The appearance 


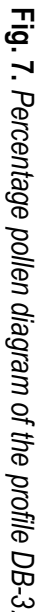
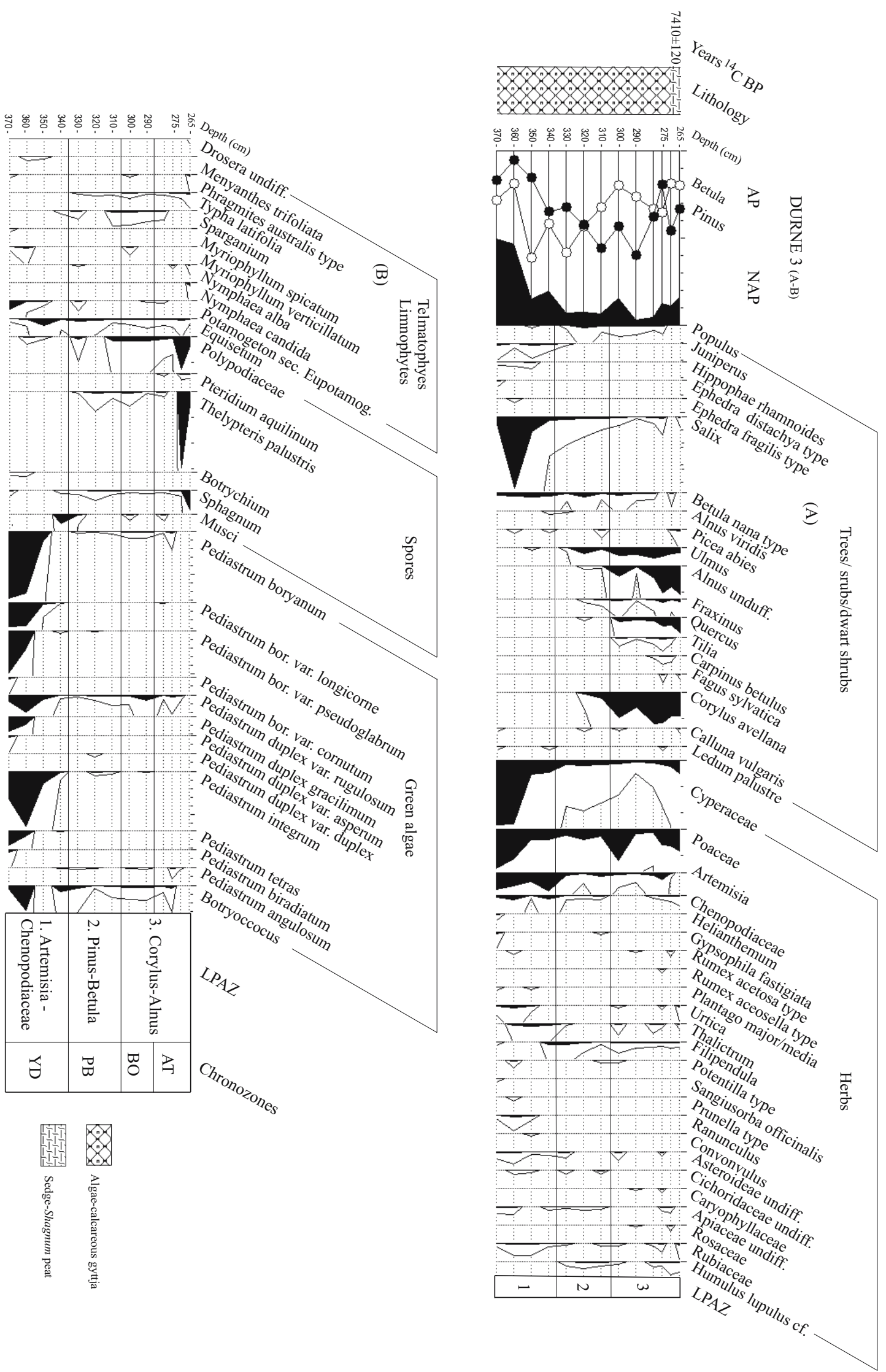
of species with higher thermal requirements, such as Typha latifolia and Nymphaea alba (in the profile DB-2) stresses climate warming at that time. The rise of the telmatophyta sum can indicate the rise of water level and the development of wide littoral zone in the shallow parts of the lake. The amount of Pediastrum coenobia decreased.

\section{Corylus LPAZ (DB-1; 520-460 cm; about 8600- 6900? BP)}

The zone is correlated with the Boreal chronozone and presumably, part of the Atlantic chronozone. During the Boreal chronozone, pine-birch forests with the changing proportion of these two components still grew. Mesophilous deciduous trees (alder, oak and ash) started their expansion. Their appearance favoured differentiation of forests. Elm and ash with admixture of oak may have formed the first patches of elm-ash wetland forest on wetter habitats. Rather low pollen values of ash $(<1 \%)$, especially in the younger phase of the zone, indicates that elm and alder were the predominant taxa in riverine forests growing on not much waterlogged grounds. Sporadically found pollen grains of Picea can indicate that spruce could have singly appeared in the communities with alder.

Rather high pollen values of Corylus (13.8\%) indicate that hazel was expanding rapidly and occupying clearings and edges of the forests. Hazel developed plentifully also in other sites of the Polesie in the Boreal chronozone. Such percentage values of Corylus are typical for Eastern Poland (Miotk-Szpiganowicz et al., 2004). In the younger phase of the zone the frequencies of hazel gradually decreased $(6.4 \%)$. The reduction of Corylus shrubs was connected with increasing density of deciduous forests. Consistently increasing pollen values of alder, oak, ash and lime indicate the further differentiation of forests. An extremely rapid expansion of Alnus took up the surrounding of the Durne Bagno around 6000 BP, which was explained in the chapter "Remarks about stratigraphy". Similarly to the other sites of the Lake District, lime entered the early Holocene forests of the Polesie as the last atlantic species. Dwarf Betula nana persisted still in the surroundings of the lake.

The rise of the NAP pollen and Sphagnum spores indicate that peat bog developed around the lake basin. The amount of Pediastrum coenobia decreased in the lake.

\section{Alnus-Quercus-Tilia-Ulmus LPAZ (DB-1; 460-215 cm; 6900?-3400 BP)}

The zone corresponds to the middle and late phases of the Atlantic and early phase of the Subboreal chronozones. At that time, the landscape was dominated by mixed deciduous forests. Three distinguished subzones indicate the differentiated succession of communities.

- Alnus subzone (DB-1; 460-370 cm; 6900-5400 BP)

Both alder and oak reached here the greater proportions in the forests about $5990 \pm 40$ BP, i.e. about 200 years later than in the vicinity of neighbouring Lake Moszne (Bałaga et al., 1992). Similar conclusions can be drawn from the curve of lime, which played important role (confirmed by the pollen values exceeding $1 \%$ ) also considerably later than in other sites of the Lake District.
Alderwoods of wet and waterlogged habitats predominated near the examined lake basin in the middle part of the Atlantic chronozone. The main expansion of Alnus might have been initiated by waterlogging and rising ground waters tables (Birks, 1986). Here, Alnus may spread around the lakes on the wettest grounds partly covered by birchwoods as is suggested by a fall in Betula pollen curve, but also on water-logged lake shores where herbaceous communities development until then. The consistently increasing values of Fraxinus excelsior pollen indicate that ash played an important role in forests forming probably the communities resembling the modern ash-elm and ash-alder riverine forests. The role of oak also increased, together with pine it formed mixed - pineoak forests with Pteridium aquilinum developing in the understorey. On more fertile soils - oak formed forests with admixture of elm, ash and lime. The decrease of the Pinus and Betula pollen values indicates that pine-birch forests remained only on poor sandy soils during the climatic optimum. Calluna vulgaris developed in these open pine forests. Viscum, pollen indicator of climatic optimum, was also present in these forests.

- Quercus subzone (DB-1; 370-305 cm; 5400-4800 BP)

The higher values of Quercus pollen evidence the expansion of oak forest in the landscape of the described area at the end of the Atlantic and at the beginning of the Subboreal chronozones. The proportion of oak (cf. $Q$. petraea) increased in mixed coniferous forest. On the other hand, the waterlogged areas were probably drained, as evidenced by the decreasing values of alder pollen and oak (cf. Q. robur) could have encroached on them. The maximum spread of lime took place at the end of the subzone. Lime was a component of oak forests and could be also found in riverine communities, together with elm and ash. The increasing percentages of ash pollen evidence the changes in the composition of these communities. Hazel was still abundant in forests understorey as evidenced by Corylus pollen values, which increased again in this subzone. Pteridium aquilinum still abundantly developed in pine and mixed forest and Calluna vulgaris on poorer habitats. Hedera helix pollen - a Mediterranean-Atlantic species - was found too.

In the end part of the subzone the distinct increase of elm pollen values lasted about 300 years and was simultaneous with the decrease of the curves of Alnus, Pinus and partially Quercus. The modification in forests composition in the Durne Bagno environs at that time was probably connected with the change of hydrologic conditions. Locally formed moderately humid habitats could have favoured the development of elm. The appearance and rising pollen values of such taxa as Plantago major/media, Rumex and Urtica can indicate the simultaneous anthropogenic changes in forests structure at that time. The decreasing sporomorph values of Bryales moss and consistently increasing those of Sphagnum suggest that the conditions at the peat bog were changing towards more oligotrophic.

- Alnus-Corylus subzone (DB-1: $305-215$ cm; 4800$3400 \mathrm{BP}$ )

In this subzone, which corresponds to the early Subboreal chronozone, the role of elm in forests in the Durne Bagno surroundings became consistently smaller. The 
decline of elm took place here about 200 years later than in the neighbouring Moszne site (Bałaga et al., 1992). The decrease of elm pollen values in the analysed diagram is simultaneous first with the rise of Pinus and Fraxinus excelsior and next with Betula and Corylus percentages. The reduction of elm in the forests on wet habitats favoured the development of ash and shrub communities with birch, which quickly expanded on new areas as a pioneer species. Reduced shading formed also better conditions for hazel development. Alderwoods became dominant from about 4500 BP. The continuous curve of Picea indicates that spruce could have occurred in those communities as an admixture. The Lublin Polesie is situated in area of the dispersed occurrence of spruce; nowadays spruce forms small stands of PiceoQuercetum in the Łęczna-Włodawa Lake District (Fijałkowski, 1957). Pollen values of elm and ash reaching several percentages stress their considerable role in forests on wet and moderately wet habitats. However, oak forests played dominant role on the latter habitats though the curve of oak pollen decreases after culmination to $13.5 \%$ about 4000 BP. Between 4400 and 3500 BP the Quercus curve decreases to $4.8 \%$. This fall was associated with the replacing of oak by pine and then by new forest components: hornbeam and beech. However, between about 5000 and 3500 BP the contribution of hornbeam in the surroundings of Durne Bagno was rather low in comparison to that recorded in other sites of the Polesie (Bałaga, 1991 and 2004).

Higher values of Artemisia pollen are recorded since the beginning of the zone, first pollen grain of Plantago lanceolata appears and then of Cerealia. Thus, the observed fluctuations of tree curves could have resulted not only from changeable climatic and hydrologic conditions but also from forest clearance associated with human economic activities. The decrease of Sphagnum spore values in the younger phase of the zone (from about 4400 BP) stresses a change in peat bog vegetation succession. This change, i.e. the sedentation of sedge-cottongrass peat, could have been conditioned by different overlapping factors, including human activities (see chapter "Remarks about stratigraphy").

\section{Carpinus LPAZ (DB-1; 215-30 cm; 3400-440 BP)}

The expansive development of hornbeam (pollen values of Carpinus betulus increase to $9.3 \%$ ) caused a considerable change in the forests surrounding Durne Bagno. Hornbeam is a component of deciduous forests. Together with oak, maple and lime it forms the second stratum of trees forming a dense layer. The spread of shady hornbeam forests significantly limited the development of hazel shrubs from about $3150 \mathrm{BP}$, i.e. about one thousand years later than near the Lake Moszne (4400 BP). The frequencies of Corylus pollen decrease almost three times (to $3-4 \%$ ), though two short episodes are recorded about 1800 and $1200 \mathrm{BP}$, when they reach $7-8 \%$. The role of pine, birch, hornbeam and anthropogenic indicators was variable, so three subzones are distinguished.

- Pinus-Betula subzone (DB-1; $215-115$ cm; 3400$1700 \mathrm{BP}$ )

Fluctuations of the curves of Pinus and Betula reflect intraspecies competition in the vicinity of the examined site. Still high values of Corylus pollen in the older part of the subzone could have resulted from the presence of hazel in the surroundings of the peat bog. Hornbeam played more and more important role in deciduous forests. Its expansion during this subzone, similarly to the one of Fagus sylvatica might be explained by the anthropogenic forest disturbance being here only a stimulating factor (Ralska-Jasiewiczowa et al., 2004). The maximum development of hornbeam communities took place in the early and final parts of the subzone; their smaller role in the middle part was associated with human activities. Matuszkiewicz (2002), considering the distribution of oak-hornbeam forests with lime, in which hornbeam is the most important tree, suggests that limiting factors include a mean May temperature above $11^{\circ} \mathrm{C}$ and a July temperature above $16-17^{\circ} \mathrm{C}$. Beech could have formed an admixture in the forest as its pollen values reached $4.0 \%$ in the final part of the subzone. Huntley and Birks (1983) assumed that the beech pollen values of $>2 \%$ indicate its local, scattered presence in vegetation communities. Today beech doesn't occur in the forests of the ŁęcznaWłodawa Lake District (compare Bałaga, 2007). The factors controlling its north-east limit are not quite clear, as the amount of precipitation and temperature conditions are sufficient for the development of beech woods (Matuszkiewicz, 2002). Fir, today does not participate in the forest of the studied area neither (Fijałkowski, 1957); Abies alba pollen appears sporadically in this subzone. Till about 2200 BP Alnus was frequent in forests. The distinct decrease of its pollen values towards the end of the subzone was probably related to drier conditions. This hydrological change, as well as human activities (indicated by the occurrence of charred leaflets of Sphagnum), contributed to the renewal of forests with oak, hornbeam and elm at that time. A new rise of the Sphagnum spore values indicates the short-lived succession changes at the peat bog, which started at about 2770 BP. Sedge-cottongrass communities developed again at the end of the subzone.

\section{- Betula subzone (DB-1; 115-45 cm; 1700-700 BP)}

Rather high pollen values of birch found in the DB-1 (higher than those of pine) are not common in the younger Holocene pollen diagrams from the Polesie; the pollen percentages of Pinus usually predominate over the Betula pollen frequencies. Thus, the high values of Betula are probably of local nature and resulted from the presence of birch on the peat bog. In the succession of communities surrounding the Durne Bagno the main role was played by Quercus, Carpinus and Corylus. The changing pollen values of these taxa evidence the changes in forest composition at that time. Alder played a greater role in the older part of the subzone, indicating greater waterlogging of the examined area. The decrease of alder pollen values in the younger part of the subzone corresponded with the increased frequencies of Betula and then Quercus pollen; birch could faster expand in the first period of disturbed hydrological balance and then Quercus robur could encroach on more dried peat bog area.

Besides the soil-hydrologic conditions also man had an impact on the composition of forests. Human economic activities are confirmed by higher pollen frequencies of anthropogenic indicators and depressions in the 
curves of hornbeam and oak. Clearings in those shady forests probably favoured temporary expansion of hazel. Beech could have been present in those forests as its pollen values still reach $1.8 \%$ in the subzone. Still only single pollen grains of Abies alba.

- NAP subzone (DB-1; 45-30 cm; 700-440 BP)

In this subzone there is increased human activity, which is stressed by the maximum values of the NAP sum (including anthropogenic indicators such as Cerealia, Plantago lanceolata, Rumex). An open landscape dominated and forests occupied smaller areas. The conditions for Sphagnum were favourable again; the peat bog was probably not used for pastural husbandry. A high degree of deforestation indicates that human activities were carried out on larger parts of the area around Durne Bagno.

\section{DEVELOPMENT AND TRANSFORMATION OF LAKE ECOSYSTEM INTO PEAT BOG}

\section{Late Glacial}

\section{Older Dryas chronozone}

Lacustrine accumulation in the Durne Bagno started directly on sands or silts of the Odra Glacial; moss peat found in most lake bottoms of the Lęczna-Włodawa Lake District (Wojciechowski and Więckowski, 1971; Bałaga et al., 1983 and Bałaga, 1991, 2007) - does not occur here. In the developing lake Potamogeton sec. Eupotamogeton, Myriophyllum spicatum and Characeae were present (Salix-Artemisia subzone; Table 7). M. spicatum is a component of a pioneer community of mineral habitats in quiet waters (Matuszkiewicz, 2001).The lake, at first shallow, was rich in Pediastrum and Botryoccocus colonies too (Fig. 8). Both genera with wide ecological spectrum and indicator species of Pediastrum occurred in large numbers. In the initial phase of lake development, its water was cold as indicated by the occurrence of Pediastrum kawraiskyi coenobia - species of boreal-alpine nature, representative of cold and pure oligotrophic waters (Komarek and Jankowska, 2001). The occurrence of Pediastrum integrum also indicates pure oligotrophic to dystrophic waters. The absence of Cladocera species with higher thermal requirements indicates cold water, too (Szeroczyńska, 2003). The appearance of Bosmina longispina at the end of the chronozone was probably associated with the rising water level. The accumulated deposits (clayey and algae-carbonate gyttja) with high content of mineral components $(>90 \%)$, including erosion indicators ( $\mathrm{K}$ and $\mathrm{Na}$ ) and also low total pollen concentration evidence open landscape around the developing lake (Fig. 9).

\section{Alleröd chronozone}

The development of forests and reduction of open areas gradually limited aeolian processes and the supply of mineral material to the lake. In the older part of the Alleröd the content of mineral material in deposits was still rather high (90-70\%) and it distinctly decreased (to 30$40 \%$ ) in the younger part (from a depth of $710 \mathrm{~cm}$ ). This change is marked by the change in total pollen concentration and in the chemical composition of the deposit by the peaks in the Fe, Mn, Mo, P, Cd curves. These elements are negatively correlated with $\mathrm{Zn}, \mathrm{Cu}, \mathrm{Ni}, \mathrm{Co}$ and $\mathrm{Cr}$ in the younger part of the Alleröd. The increased contents of the mentioned elements were probably at least partially connected with the increased productivity of the lake resulting from climate warming. This is indicated by the occurrence of Typha latifolia developing in reedswamp belt and the larger number of Cladocera species both in littoral zone and open water. Cold-demanding species Pediastrum kawraiskyi disappeared but other Pediastrum and Botryoccocus species developed jet intensively (especially Pediastrum integrum, $P$. duplex var. rugulosum and $P$. boryanum var. longicorne). Characeae disappeared and Nymphaea sp., Najas flexilis and N. marina were present (Table 7). The Fe/ $\mathrm{Mn}$ and $\mathrm{Cu} / \mathrm{Zn}$ ratios (Fig. 9) indicate variable redox conditions and so water level fluctuations. These changes were probably connected with the lake deepening due to progressing degradation of permafrost and slow subsidence of substratum (Bałaga et al., 2006 and Dobrowolski, 2006). More abundant Cladocera indicate an increase in the trophic status of the lake in comparison with the previous chronozone.

\section{Younger Dryas chronozone}

Lacustrine deposits accumulated also in shallower parts of the lake (DB-2) and they usually contain calcium carbonate. Deposits from its deeper parts are carbonatefree. The content of calcium carbonate, one of the main components of lacustrine deposits, is controlled by many factors (Nowaczyk and Tobolski, 1981; Rzepecki, 1985 and Wojciechowski, 2000). Its supply is connected with the intensity of chemical denudation of a catchment and its content can be also influenced by biological decalcifi-

Table 7. Macrofossils of water plants in the bottom part of the profile DB-1; + (1-5), ++ (5-10), +++ (>10 specimens).

\begin{tabular}{|c|c|c|c|c|c|c|c|}
\hline 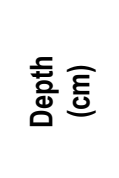 & 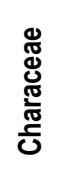 & 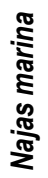 & 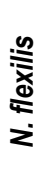 & 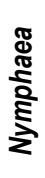 & 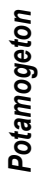 & $\begin{array}{l}\overline{\mathscr{D}} \\
\stackrel{\text { Den }}{\Sigma}\end{array}$ & 题 \\
\hline $700-705$ & + & & + & & & + & \multirow{14}{*}{ 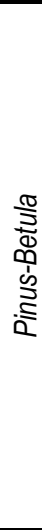 } \\
\hline 705-708 & & & + & & & + & \\
\hline $712-715$ & & + & & + & & + & \\
\hline $715-718$ & & & & + & & + & \\
\hline $718-720$ & & & + & & & + & \\
\hline $720-723$ & & & & & & + & \\
\hline $723-725$ & & & & + & & + & \\
\hline $725-727$ & & & & & & + & \\
\hline $727-730$ & + & & & + & & + & \\
\hline $730-732$ & + & & & & & + & \\
\hline $732-733$ & + & & & & & + & \\
\hline $737-738$ & + & & & & & + & \\
\hline $737-740$ & + & & & + & & + & \\
\hline $740-742$ & + & & & + & & + & \\
\hline $742-745$ & ++ & & & & & + & \multirow{6}{*}{ 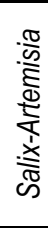 } \\
\hline $746-747$ & +++ & & & & & & \\
\hline $747-748$ & +++ & & & & & & \\
\hline $762-763$ & +++ & & & & ++ & & \\
\hline $767-768$ & & & & & + & + & \\
\hline $772-773$ & + & & & & + & + & \\
\hline
\end{tabular}




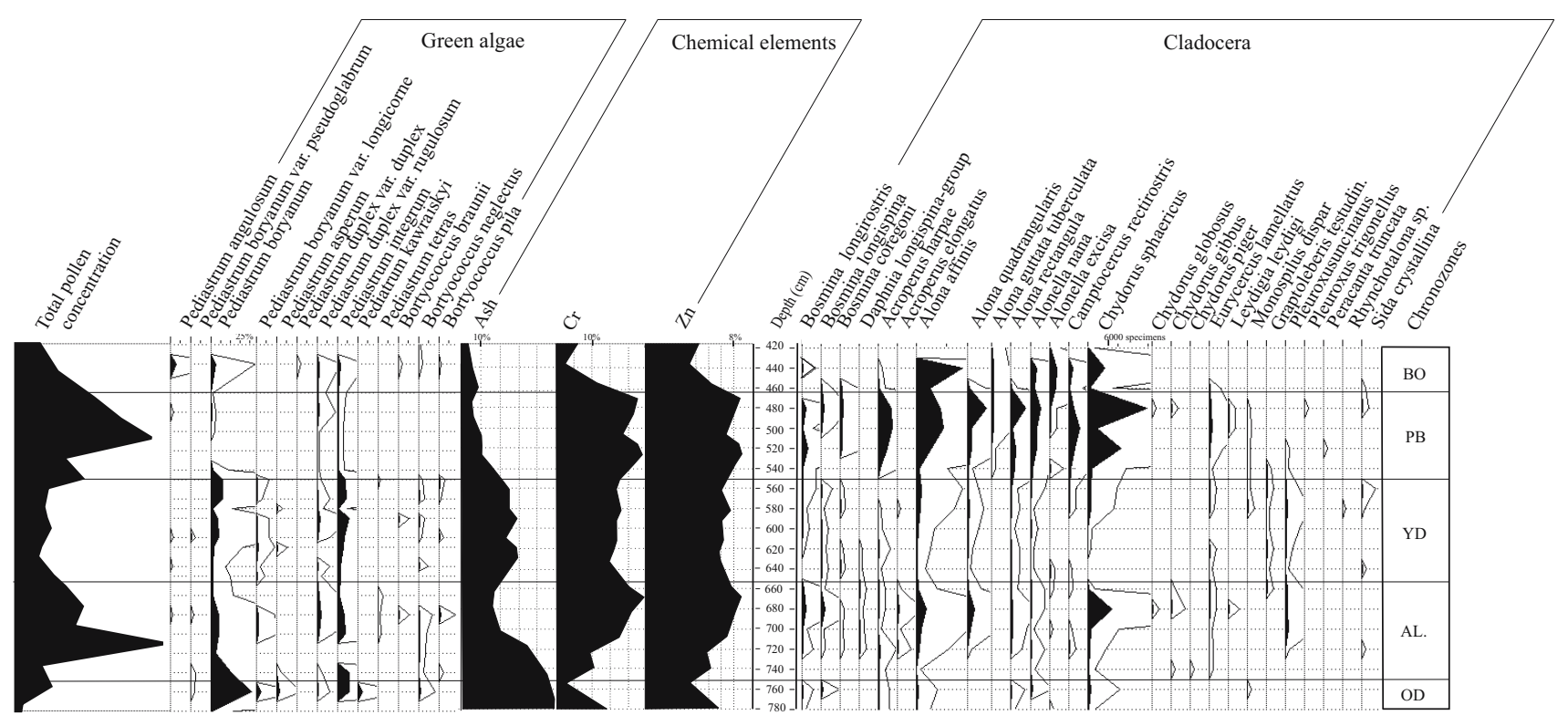

Fig. 8. Comparison of the selected palynological, chemical and faunal elements in limnic deposits in the profile DB-1.

cation of water by macrophytes. When the examined lake became larger the spread of macrophyte zone favoured the accumulation of carbonates in shallower parts. The deposits formed at that time (DB-1) are characterized by higher erosion indicators, i.e. the content of mineral substance (to $60 \%$ ) and of macroelements $(\mathrm{Mg}, \mathrm{K}, \mathrm{Na}, \mathrm{Al})$. They are positively correlated with some microelements: $\mathrm{Ti}, \mathrm{V}, \mathrm{Cu}, \mathrm{Ni}, \mathrm{Co}$. The $\mathrm{Fe} / \mathrm{Cu}, \mathrm{Cu} / \mathrm{Zn}$ ratios evidence reduction conditions and so lower oxygenation of bottom water layers. Such conditions were not favourable for the development of Cladocera fauna so its frequency decreased. Species of lower thermal requirements were present (Szeroczyńska, 2003). After the decrease in the older phase, the contribution of algae increased again in the younger one, in it especially of cosmopolitan species $P$. boryanum var. boryanum and $P$. integrum. The occurrence of $P$. integrum evidences oligotrophic nature of the lake. The absence of Pediastrum kawraiskyi can indicate that lake water was warmer than in the initial phase of lake development though pollen spectra confirm a considerable climate cooling resulting in the expansion of grass-Artemisia cold steppe and tundra communities and the reduction of forests. In the Late Glacial the lake was large and about 3-4 $\mathrm{m}$ deep and water level occurred at 167-168 m a.s.1. (Bałaga et al., 2006).

\section{Holocene}

\section{Preboreal chronozone}

Similarly as in pollen spectra, the boundary $\mathrm{YD} / \mathrm{PB}$ is rather sharply visible in chemical composition of deposits as the decrease in the content of mineral matter and almost all elements. Only the contents of $\mathrm{Cr}$ and $\mathrm{Zn}$ and partially $\mathrm{P}$ remain high. $\mathrm{Cr}$ and $\mathrm{Zn}$ are elements of low geochemical mobility. When released from minerals, they are quickly kept by weathering products. It is possible that their increased contents are associated with higher biological productivity of the lake and especially with the development of microfauna (Polański and Smulikowski,
1969). The curves of these elements are positively correlated with the frequency of Cladocera fauna developing in the lake (Fig. 8). The amount of Pediastrum coenobia decreased, $P$. integrum and $P$. duplex var. rugulosum occurred only in trace quantities. However, the appearance of Pediastrum duplex var. rugulosum indicates that lake water was rather warm. Presence of Nymphaea alba pollen also indicates that the water was warm and eutrophic. Today this plant is a component of NupharoNymphaetum albae and plays the main role in the successive stages of the lake becoming shallower and more overgrown. Generally, sedimentation in the lake was still varied; deposits containing carbonates accumulated in shallower parts and those carbonate-free - in the southern, deeper part of the lake. In the deeper part of the lake (DB-1) only a $25 \mathrm{~cm}$ thick layer of deposits represents this chronozone. In comparison with the results of pollen analysis of the DB-2 profile, it seems that accumulation in the deeper part of the lake was not continuous at that time.

\section{Boreal chronozone}

The contents of mineral substance and most of elements (except for Mo, $\mathrm{Zn}$ and $\mathrm{Cr}$ ) in deposits still decreased. The rise of low curve of Mo can evidence higher redox potential and more acid environment (Polański and Smulikowski, 1969; Perelman, 1971). Mobility of molybdenum in acid environment is low because $\mathrm{MoO}_{4}{ }^{2-}$ is absorbed by positively charged colloidal hydroxides of iron and aluminium and forms insoluble complex compounds with phosphates. However, it is possible that the increased amount of Mo was conditioned by vegetation and faunal composition because it plays an important role in nitrogen transformation occurring in plant and animal organisms. Faunal studies evidence the maximum development of Cladocera at that time (Szeroczyńska, 2003). The increased frequency of Chydoride stresses the occurrence of wide littoral zone, which was associated with steady or rising water level. Higher contribution of Bos- 
mina longispina and $B$. coregoni rather indicates the rise of water level. The following increase of amount of acidophilous Allona excisa and gradual decrease of Cladocera frequency indicate the gradual change towards the dystrophic lake. The greater amount of Pediastrum (mostly P. boryanum) and Botryoccocus coenobia appearing again in the younger phase of this zone was connected with a change in fauna composition. The occurrence of $P$. integrum was probably connected with more oligotrophic conditions and $P$. duplex var. rugulosum indicates that water was still warm. The presence of Nymphaea candida pollen may confirm that the lake basin became shallower and was impoverished in nutrients (Matuszkiewicz, 2001). Changeable concentration of pollen (high in the middle part of the chronozone) indicates a different rate of sedimentation, which resulted from various productivity of the lake. The approximate rate of sedimentation was estimated at about $0.3 \mathrm{~mm} / \mathrm{yr}$; however, it is probable that sedimentation hiatus occurred between the Boreal and Atlantic chronozones (early Atlantic deposits are absent).

\section{Atlantic chronozone}

A fundamental change of accumulation type took place in the lake, which progressively became shallower; in its shallower parts (DB-2 profile) this process started as early as about $7400 \mathrm{BP}$. The shoreline of the lake basin was probably differentiated and the aquatic and rush plants alternated as a mosaic. Sedge-moss or sedge-reed peat grew as a result of consistent decrease in the lake area. At that time, the lake occupied about half of the modern peat bog surface. A further progressive decrease in the depth of the central basin, deeper part of the lake, took place about 1400 years later. It is shown by algae of Pediastrum genus stopped developing in the final phase of the chronozone and the prevailing species of Cladocera (found at a depth of 460-420 cm) were acidophilous and those living in the company of macrophytes. This section of the profile is characterized by low total pollen concentration that probably evidences fast sediment accumulation. The water surface shrank, occupying less space than previously. The change of sedimentation into sedentation in the central part of the lake is dated at $5990 \pm 40 \mathrm{BP}$. At that time the lake was overgrown and turned into fen which is recorded in pollen diagram as the rise of Cyperaceae, Phragmites australis, Sparganium pollen and Musci spore values. The presence of Nymphaea alba and $N$. candida pollen may indicate the existence of a small water surface. The changes in the conditions caused some modifications in the composition of chemical elements. The content of mineral matter in peat decreases to several percent, the contents of $\mathrm{Ca}, \mathrm{Sr}, \mathrm{Na}$ and $\mathrm{Ba}$ increase and are high in sedge-moss peat accumulated in the younger phase of the Atlantic chronozone that was mostly connected with the type of vegetation forming this peat $(\mathrm{Cy}-$ peraceae, Musci, Phragmites australis, Typha latifolia, T. angustifolia and Sparganium).

\section{Subboreal chronozone}

At the beginning of the subboreal chronozone another change in the peat bog development took place. The decreasing amount of brown moss spores and increasing

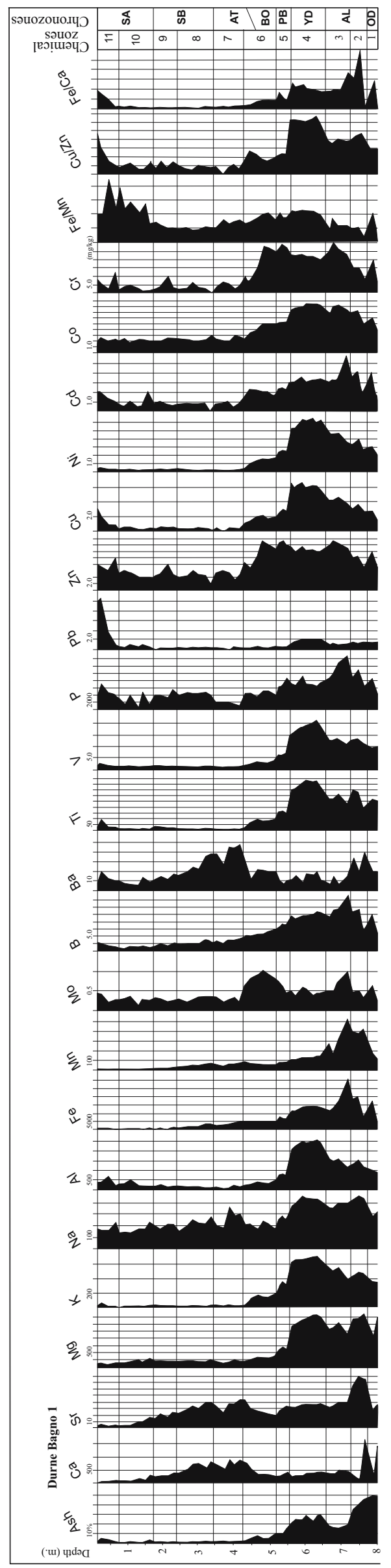

Fig. 9. Chemical composition of the deposits from the profile DB-1. 
frequency of Sphagnum spores indicate conditions favourable for developing a Sphagnum bog (Fig. 10). The change is also indicated by gradually rising curve of dwarf shrubs of the Ericaceae family. Peats are characterized by decreasing tendency of $\mathrm{Ca}, \mathrm{Sr}, \mathrm{Ba}$ and $\mathrm{Na}$ contents and continuous rise of phosphorous content from about 5000 BP. The P curve reflects the increased supply of humus material, which was probably connected with human economic activities in the surroundings of the examined site.

Peat bog communities underwent another change about $4440 \pm 40 \mathrm{BP}$ when cotton-grass-sedge communities developed. Sedentation of cotton-grass-sedge peat with very fibrous "rope-like" structure lasted about 2000 years. Sphagnum spores in the pollen diagram disappeared almost completely till about 2500 BP. The boundary between Sphagnum peat and cotton-grass-sedge peat is reflected in a gradual transition in chemical composition. The cotton-grass-sedge peat is characterized by further decrease of the $\mathrm{Ca}, \mathrm{Sr}, \mathrm{Ba}, \mathrm{Fe}$ and $\mathrm{Mn}$ contents.

The development of cotton-grass-sedge (cotton-grass) could have been connected with human economic activities. Kulczyński $(1939,1940)$ described peat bogs in the Polesie region and distinguished cotton-grass peat bogs, which were changed by grazing. Grazed plant was Eriophorum vaginatum. Grazing took place in the spring where leaves of cotton-grass were still soft. Trees were often cut and transpiration was reduced so peat bog became more waterlogged. Intensive and long-standing pasturage resulted in destruction of "hummock and hollow" structure. Sphagnum disappeared both in hummocks and in hollows and root system of cotton-grass vigorously grew (Fig. 11). Its development was also supported by the enrichment of habitat in nitrogen and phosphorus compounds. Such a use of the peat bog could have resulted in the low values of Eriophorum pollen and in the

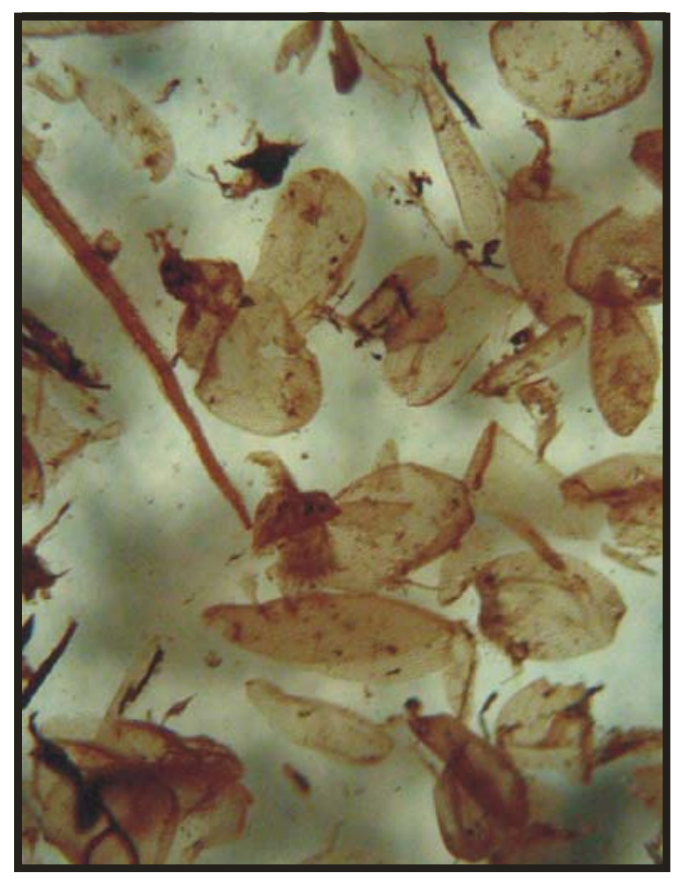

Fig. 10. Sphagnum peat from the profile DB-1 (photo by the author). disappearance of Sphagnum spores recorded in the diagram. Consistence of pollen record and archaeological data (Fig. 12) argue for such an interpretation. According to Bragg and Talis (2001) grazing and/or burning favours a predominance of graminoides (Eriophorum vaginatum, Molinia coerulea, Trichoforum caespitosum) in the bog vegetation. A Sphagnum-rich bog vegetation may have resulted from low-intensity grazing and infrequent burning.

The sedentation rate calculated for the period from 4440 to $2140 \mathrm{BP}$ is $0.56 \mathrm{~mm} / \mathrm{yr}$. High total pollen concentration, especially in the period from 3700 to $3300 \mathrm{BP}$, can indicate that sedentation rate was considerably lower but variable.

\section{Subatlantic chronozone (DB-1; 160-30 cm)}

The beginning of this chronozone brought a next change in the peat bog development. Sphagnum spores reappear in the diagram but they do not form a continuous curve indicating slow change towards the Sphagnum peat bog. The increase of Sphagnum spores started about $2500 \mathrm{BP}$ and the maximum occurred about 21002000 BP. The rise of the Vaccinium type pollen (from about 1900 BP) probably indicates that Vaccinium uliginosum grew at the peat bog and Ledum palustre appeared about 1300 BP. They usually occupied rather dry hummocks formed around pines. High values of Betula pollen can indicate that birch was also present at the peat bog. The successive decrease of Sphagnum spores in the period from 2000 to $1200 \mathrm{BP}$ and the rise of anthropogenic indicators were connected with the intensified anthropopression in the Roman period and early Middle Ages. Higher contents of mineral substance in the deposits accumulated at that time probably evidence accelerated erosion caused by forests clearance. The next development of Sphagnum is recorded in the youngest $50 \mathrm{~cm}$ of deposits, which accumulated from about $700 \mathrm{BP}$, i.e. in

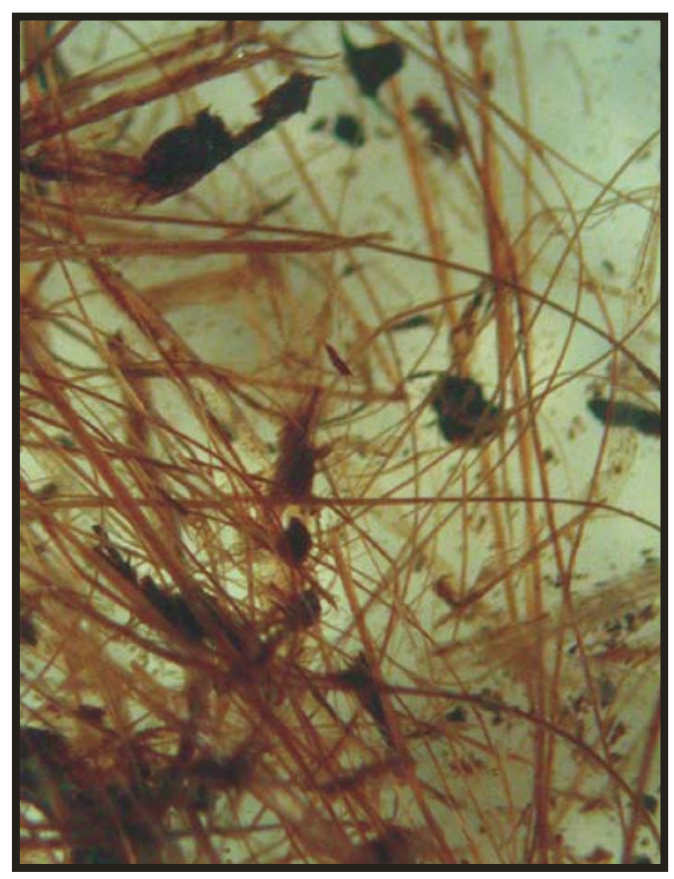

Fig. 11. Eriophorum peat from the profile DB-1 (photo by the author). 
the period determining the modern peat bog nature. The contents of heavy metals are higher in the top part of peat (especially in the youngest $25 \mathrm{~cm}$, i.e. from about $400 \mathrm{BP})$.

\section{ANTHROPOGENIC ASPECTS OF THE DE- VELOPMENT OF VEGETATION AND PEAT BOG}

The archaeological research was done within a radius of $3 \mathrm{~km}$. Such a radius was selected due to rather close vicinity of other objects (Moszne, Karaśne, Krowie Bagno) that were palynologically examined. Traces of prehistoric settlement near the Durne peat bog are rather numerous but many findings have not precise chronology (Taras 2005 and Fig. 12).

The earliest changes in the pollen diagram, interpreted as evidence of human activities, occur within the older part of Alnus-Quercus-Tilia-Ulmus PAZ representing the Altantic chronozone. They are connected with the Mesolithic populations. Mesolithic groups of the Komornicka and then Janisławicka Cultures arrived in the Polesie area during the early and middle Holocene. Local groups of the Świderska Culture probably managed to survive and adapt to the changing environmental conditions. The above-mentioned populations occupied also the elevation near the Durne Bagno (Tymczak, 1998). Eleven archaeological sites found in the examined area were defined as the Mesolithic ones (Fig. 12). However, numerous sites with flints of non-identified age can indicate that Mesolithic settlement was even denser. Mixed deciduous for- ests with Quercus, Ulmus, Fraxinus, Tilia and Corylus avellana occurring on more fertile brown soils and alderwood developing in the waterlogged areas were dominant. Pine and mixed pine forests were overgrowing sandy grounds. The herbaceous plants document disturbance mostly in dry mixed pine forest (Pteridium aquilinum, Calluna vulgaris, Melampyrum) and humid alderwoods (Humulus lupulus, Urtica, Filipendula, Thalictrum and Valeriana). The rise of the Pteridium aquilinum curve, a species well developing in open forests or sites of the fire (Latałowa, 1992), was dated only from about 5900 BP. Such late record could have resulted from not continuous accumulation of deposits (see chapter "Remarks of stratigraphy"). The increased pollen values of Urtica (especially about 5700-5500 BP) were probably connected with the occurrence of nettle in alderwoods, but could also evidence nitrophilous habitats (cf. Urtica urens) formed near human campsites. The increased pollen frequencies of Artemisia provide also evidence of ruderal habitats surrounding the Durne Bagno.

This hunting-gathering type of economy changed into agricultural-breeding one in the younger Stone Age. The expansion of Neolithic people in the Lęczna-Włodawa Lake District started when the population of FunnelBeaker Culture arrived, which left most numerous artefacts in this area (Taras, 2005). In the environs of the Durne Bagno the sites of this culture are rare (Fig. 12). The new signals of human presence in the studied area appeared about 5100 BP. The appearance of Rumex ace-

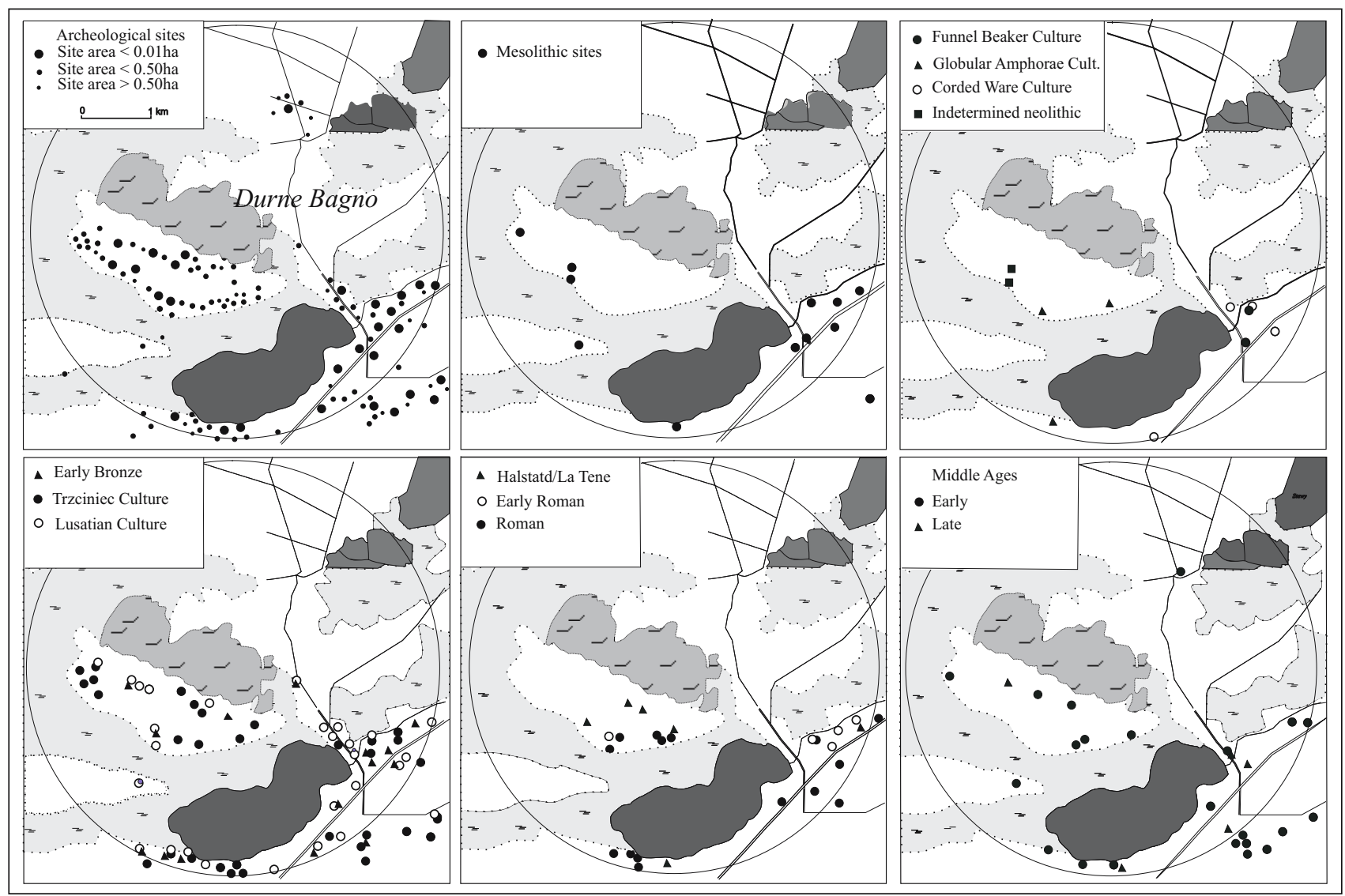

Fig. 12. Distribution of the archaeological sites in the vicinity of the Durne Bagno peat bog. 
tosa, R. acetosella, Plntago media/major and Ranunculus, might suggest the formation of small open grassland in the forests. The decrease in the Quercus and Pinus pollen values at the end of this time can indicate that people penetrated both more fertile and poorer habitats. The untypical increase of Ulmus values at that time resulted probably from local conditions, which became more favourable for this taxon after the clearance of oak forests.

A new cycle of anthropogenic change is signalled by rising pollen frequencies of ruderal taxa (Artemisia, Chenopodiaceae, Plantago lanceolata and Urtica) after the decrease in the elm curve. Curves of mesophilous tree species consistently decrease. The deforestation became more evident, grazed clearings were formed both on more humid soils, as confirmed by the occurrence of Rumex acetosa and on drier habitats with Rumex acetosella. The first single grains of Cerealia (Triticum) appear, indicating the existence of small corn-fields. The younger part of the Neolithic is usually represented by scattered, shortlived, small settlements. Small burial grounds or single graves of people of the Globular Amphorae and Corded Ware Cultures also date from that period (Bronicki, 1991). Three sites of Globular Amphorae Culture and four sites of Corded Ware Culture were found near the Durne Bagno (Fig. 12). People of these cultures were nomads and pasturing was their main type of economy. It is possible that the area of the examined peat bog was enough accessible to use it as pasture at that time. Those unquestionable changes caused in natural environment by the Neolithic man are not clearly reflected in the AP/NAP ratio. Probably the area of cultivated fields was small and fields frequently lying fallow were again overgrown by pioneer vegetation.

Scattered groups of people appeared in the examined area at the beginning of the Bronze Age. First it was population of the Mierzanowicka Culture and next - of the Strzyżowska Culture. However, long-lasting settlement started only when people of the Trzciniec Culture arrived. Greater agglomerations of that culture are recorded in the central part of the Lake District, just near the Durne Bagno and nearby Krowie Bagno and Lake Wytyckie (Taras, 1995 and Bronicki, 1991). Twenty-four sites are related with the Trzciniecka Culture and thirteen are dated to the Early Bronze Age (Fig. 12). The increasing pollen values of anthropogenic indicators, associated with pasturage and agriculture, evidence greater changes in vegetation cover. Curves of mesophilous tree species still fall and distinct decrease is visible in hornbeam curve. The appearance of first pollen grain of Secale cereale should not be related to rye growing. Rye probably occurred as weed in other cereal crops. The economy of Trzciniec population was mostly based on animal husbandry exploiting open grasslands for grazing, agriculture was of minor importance. Type of accumulated peat and disappearance of peat mosses were probably associated with pastoral use of peat bog (see chapter "Development and transformations..."). That rather intensive use of peat bog lasted to about $2500 \mathrm{BP}$, i.e. when the Lusatian population settled the Polesie area. Definite majority of known sites of this culture is found in the southern and central parts of the Lake District (Taras, 2005), in it twenty-six near the Durne Bagno peat bog.

The second half of the first millennium $\mathrm{BC}$ is archaeologically worse recognized (Taras, 2005). Few surface findings are dated to the La Téne period. Five sites dated to the Halstadt/La Téne and five from the Early Roman period were found in the vicinity of the Durne Bagno.

The fall of the curves of Artemisia, Chenopodiaceae and other meadow taxa in the La Téne and Early Roman periods indicates the decrease of human economic activities and the regeneration of communities with oak, hornbeam, elm and beech on more fertile habitats. Cottongrass pasturages became probably abandoned and Sphagnum developed again at the peat bog (see section "Development and transformation..."). Distinctly reduced human activities probably indicate the movements in the settlement within the regions. Situation changed only in the Roman period when the peat bog could have been used as a pasture once more, cotton-grass again vigorously grew and cotton-grass peat accumulated. At that time the proportion of anthropogenic indicators did not differ considerably in comparison to that in the Bronze Age. Similarly as in the former periods, the AP/NAP ratio does not indicate a considerable deforestation. However, the fluctuations of the tree curves probably evidence the changes in forest composition. The beginning is indicated by a rise in Betula and decreases in Fraxinus excelsior and Ulmus, followed by sharp reduction in Carpinus betulus and Quercus pollen values.

In the next period of the increased content of anthropogenic indicators, i.e. in the $2-6^{\text {th }}$ century $A D$, according to the interpolated dating results, rather distinct decrease of pine pollen values is recorded. At that time the clearance of forests was probably carried out mainly on drier habitats so it affected pine forests. Forests with considerable contribution of alder, elm and ash still grew on humid habitats. Fluctuations of the curves of other deciduous trees indicate the composition changes of forests also on more fertile habitats - after short decreases, the curves of hornbeam and next of oak rise again for a short time. Those rather dynamic changes in forests could have been caused not only by human economic activities but also in large measure by hydrologic factors - higher groundwater level. The occurrence of Secale cereale pollen grains should be probably related to intentional growing of rye. The values of Cerealia are $0.2 \%$.

The rise of the oak frequencies (corresponding to the $6^{\text {th }}$ century) is synchronous with the beginning of persistent decrease of the elm and ash curves. In the further succession of forests the next fall of tree curves (Quercus, Carpinus) is simultaneous with the low or even disappearing frequencies of some anthropogenic indicators. Their very low contribution was probably connected with the migration of settlers away from the site. Chronologically, the decrease of anthropogenic indicators after the Roman period is related to the decline of settlement in the Migration period. The interpolated age of the examined deposits does not correspond with this statement. However, it seems to be underestimated for about 200 years. The variable total concentration of pollen stresses the differentiated rate of deposit accumulation, so it is possi- 
ble to correlate the phase of decreased anthropogenic indicators with the Migration period. Regeneration of pine forests took place at that time and then the expansion of Betula and Quercus occurred, which was probably favoured by less humid conditions. Quercus could have developed on partially dried, more fertile habitats but more favourable light conditions, caused by thinning of forest cover, could have also influenced oak flowering.

In the further forest succession (up to the $10^{\text {th }}$ century according to the interpolated age of peat) both pine and alder were replaced by birch (B. pubescens) as a species of high hydrologic tolerance. These data can indicate rather local changes; humid conditions favoured the restoration of alder near the examined peat bog. Restoration of hazel also took place; the development of hazel shrubs was connected with a considerable clearance of forests.

The reappearance of anthropogenic indicators in the $10-12^{\text {th }}$ century was associated the reduction of birch and pine communities as indicated by the decrease of Betula and then Pinus curves. The increase of the pollen values of Carpinus, Quercus and Fraxinus indicates that forests on more fertile habitats were not devastated at that time. They were probably treated as the source of varied food. The changes occurred also at the peat bog. Sphagnum developed again but the formation of Sphagnum peat bog was disturbed again in the $13-14^{\text {th }}$ century. This fact was simultaneous with the next decreased contribution of anthropogenic indicators. Their fall was connected with the expansion of birch shrubs and a small regeneration of forests with lime and elm. The contributions of oak and hornbeam in forests were reduced. A depression in the Alnus curve (corresponding to the $10-14^{\text {th }}$ century) probably evidences drier conditions. The dried grounds were occupied by birch, which won ecological competition in the conditions of disturbed hydrological equilibrium. Pine, oak and hornbeam encroached on the deforested areas later.

The successive changes expressed by a distinct increase of the NAP sum and of anthropogenic indicators were recorded in the two upper samples with the interpolated age calculated at the $14-15^{\text {th }}$ century. They indicate crop intensification and forest clearance both on fertile and poor habitats in the late Middle Ages. This period is characterized by the increased population density and crop intensification resulting from the transformation of the two-field system into three-field system. The development of feudal possession of estate determined the delineation of more stable field/forest boundaries (Maruszczak, 1988).

The successive development of Sphagnum (recorded from a depth of $30 \mathrm{~cm}$ ) can suggest that grazing was ceased at the peat bog and modern peat bog developed.

In the light of rather enigmatic materials from surface investigations, the oldest Slav settlement was dated to the $6^{\text {th }}$ or at the latest $7^{\text {th }}$ century AD (Taras, 2005). Nineteen archaeological sites are located near the Durne Bagno and others near the neighbouring Lake Wytyckie. A small number of archaeological sites dated from the Middle Ages seems to confirm that a direct impact of man on the development of the Durne Bagno peat bog (when it was used as a pasture) gradually declined. Its further functioning (during the last fifty years) was determined by hydro- logical conditions influenced both by climate and human economic activities.

\section{FINAL REMARKS}

Durne Bagno is one of many sites in the ŁęcznaWłodawa Lake District analysed on the basis of the results of interdisciplinary research, in it palynological studies. Vegetation succession of the Late Glacial and Holocene in the Durne Bagno site was generally similar as in other examined sites. The record of late development of mixed deciduous forests, in pollen diagram Durne Bagno 1, resulted probably from the occurrence of hiatuses during deposit sedimentation (see chapter "Remarks about stratigraphy"). However, special phenomena are the increased values of Ulmus pollen at the end of the Atlantic chronozone and rather slow encroachment of Carpinus on the area near the post-lake peat bog. Man influenced the lake-peat bog complex as early as in the Mesolithic. Human activities became stronger and stronger with the intensification of settlement and directly affected the next phases of peat bog development. Geologic structure, i.e. the occurrence of thick fluvioglacial series underlying the palaeolake Durne Bagno without direct connection with karstified bedrock, determined favourable conditions for the development of peat bog (Bałaga et al., 2006). Its formation started around 5200 BP but its further evolution was modified by pastoral economy of Neolithic humans, especially of the Bronze Age population. Sphagnum disappeared in the periods of more intensive settlement and root system of cotton-grass vigorously grew as a result of grazing. Human activity is stressed not only by the occurrence of pollen anthropogenic indicators but also by higher content of phosphorus in accumulated peat. The succession of peat bog, from reed-sedge-moss peat developing on lacustrine deposits to cotton-grass-Sphagnum peat, is also recorded in the changeable contents of chemical elements. Reed-sedge-moss peat is characterized by higher contents of $\mathrm{Ca}, \mathrm{Sr}$ and $\mathrm{Ba}$. Their concentrations are lower in cotton-grass-Sphagnum peat because the conditions at the peat bog were more oligotrophic. Top layers of the peat bog contain higher contents of heavy metals $(\mathrm{Pb}, \mathrm{Cu}$ and $\mathrm{Cd}$ ).

Sedimentation of lacustrine deposits underlying peats started in the Older Dryas and lasted to the middle Holocene. In comparison with peats, lacustrine deposits are characterized by high contents of mineral material and almost all determined chemical elements. In the Late Glacial series the lowest content of mineral material is found in the chemical zone corresponding with the Alleröd chronozone. Limnic phase of the Durne Bagno development is characterized by a positive correlation between the contents of $\mathrm{Zn}$ and $\mathrm{Cr}$ and the frequency of Cladocera fauna.

\section{ACKNOWLEDGEMENTS}

The studies of sediments of Durne Bagno peatbog were partially supported by Grant No 6PO4E 02517 from Polish State Committee for Scientific Research. 


\section{REFERENCES}

Bałaga K, 1991. The development of Lake Łukcze and changes in plant cover of the south-western part of the Lęczna-Włodawa Lake District in the last 13000 years. Acta Palaeobotanica 30(1,2): 77-146.

Bałaga K, 2004. Changes of vegetation in Lake Perespilno environs (Lublin Polesie) in the Late Glacial and Holocene. Acta Palaeobotanica 44(2): 147-166.

Bałaga K, 2007. Changes in the natural environment recorded in the sediments of the Karaśne lake-mire complex (Lublin Polesie, E Poland). Geochronometria 29: 1-21, DOI 10.2478/v10003-0070032-z.

Bałaga K, Buraczyński J and Wojtanowicz J, 1983. Budowa geologiczna i rozwój torfowiska Krowie Bagno (Polesie Lubelskie) (Geological Structure and Development of the Krowie Bagno Peatland (Polesie Lubelskie)). Annales Universitatis Mariae CurieSkłodowska B, 35/36: 37-62.

Bałaga K, Pidek A and Rodzik J, 1992. Preliminary studies on vegetational changes since Late Glacial times at the peat bog near Moszne Lake (Lublin Polesie, E Poland). Veröffentlichungen des Geobotanichen Institutes der ETH, Stiftung Rübel, Zürich 107: 319-330.

Bałaga K, Dobrowolski R and Rodzik J, 2006. Późnoplejstoceńska i holoceńska ewolucja torfowiska Durne Bagno (Polesie Lubelskie) (Late Pleistocene and Holocene evolution of the Durne Bagno peat bog (Lublin Polesie)). Przeglad Geologiczny 54(1): 68-72.

Berglund BE and Ralska-Jasiewiczowa M, 1986. Pollen analysis and pollen diagrams. In: Berglund $\mathrm{BE}$, ed., Handbook of Holocene Palaeoecology and Palaeohydrology. Chichester - New York - Brisbane - Toronto - Singapore, Wiley J and Sons Ltd.: 445-484.

Birks HJB, 1986. Late-Quaternary biotic changes in terrestrial and lacustrine environments, with particular reference to north-west Europe. In: Berglund BE, ed., Handbook of Holocene Palaeoecology and Palaeohydrology. Chichester - New York - Brisbane Toronto - Singapore, J. Wiley and Sons Ltd.: 3-65.

Borowiec J, 1990. Torfowiska regionu lubelskiego (Mires of the Lublin region). Warszawa, Państwowe Wydawnictwo Naukowe: 348pp (in Polish).

Bragg OM and Talis JH, 2001. The sensitivity of peat-covered upland landscapes. Catena 42(2-4): 345-360, DOI 10.1016/S03418162(00)00146-6.

Bronicki A, 1991. Późnopaleolityczne i wczesnobrązowe toporki kamienne $\mathrm{z}$ obszaru województwa chełmskiego (Late Palaeolithic and Early Bronze stone axes from the area of Chełm Voivodship). In: Gurba J, Kmieciński J, Kowalczyk J, Łopuszko T and Szczygieł R, eds., Schylek neolitu i wczesna epoka brazu w Polsce środkowowschodniej. Lubelskie Materiaty archeologiczne VI. Lublin, Wydawnictwo Uniwersytetu Marii Curie-Skłodowskiej: 297-340 (in Polish)

Bronk Ramsey C, 2001. Development of the radiocarbon calibration program OxCal, Radiocarbon, 43 (2A): 355-363.

Dobrowolski D, 2006. Glacjalna i peryglacjalna transformacja rzeźby krasowej północnego przedpola wyżyn lubelsko-wotyńskich (Polska SE, Ukraina NW) (Glacial and perglacial transformation of karst relief in the north foreland of the Lublin-Volynia uplands (SE Poland, NW Ukraine)). Lublin, Wydawnictwo Uniwersytetu Marii Curie-Skłodowskiej: 184pp.

Faegri K and Iversen J, 1989. Textbook of pollen analysis, III ed. Munksgaard, Copenhagen, Denmark: 295pp.

Fijałkowski D, 1957. Badania nad ekologia drzew leśnych w woj. lubelskim (Studies on ecology of forest trees in the Lublin Voivodship). Sylwan C 2(5): 21-33 (in Polish with German summary).

Goslar T, Bałaga K, Arnold M, Tisnerat N, Kuźniarski M, Chróst L, Walanus A and Wieckowski K, 1999. Climate-related variations in the composition of the Late Glacial and early Holocene sediments of Lake Perespilno (eastern Poland). Quaternary Sciencie Reviews 18(7): 899-911, DOI 10.1016/S0277-3791(99)00004-9.

Granoszewski W, 1998. Late Pleistocene vegetation history and climatic changes at Horoszki Duże, eastern Poland: a palaeobotanical study. Acta Palaeobotanica, Suppl. 4: 95pp.

Huntley $\mathrm{H}$ and Birks HJB, 1983. An atlas of past and present pollen maps for Europe 0-13 000 years ago. Cambridge University Press.

Komarek J and Jankowska V, 2001. Review of the Green Algal Genus Pediastrum; Implication for Pollen-analitical Research. Berlin Stuttgart, J Cramer: 127pp.
Krupiński KM, Tobolski K, Ralska-Jasiewiczowa M and Nalepka D, 2004. Hippophä̈ rhamnoides L. Sea-buckthorn. In: RalskaJasiewiczowa M, Wasylikowa K, Tobolski K, Madeyska E, Wright Jr. HE and Turner Ch, eds., Late Glacial and Holocene history of vegetation in Poland based on isopollen maps. Kraków, W. Szafer Institute of Botany, Polish Academy of Sciences: 119-124.

Kulczyński S, 1939, 1940. Torfowiska Polesia (Mires of the Polesie). Vol.1, 2. Kraków, Nakładem autora: 777 pp (in Polish).

Latałowa M, 1992. Man and vegetation in the pollen diagrams from Wolin Island (NW Poland). Acta Palaeobotanica 32(1): 123-249.

Malicki L and Litwińczuk Z, 2002. Gospodarcze wykorzystanie Polesia Lubelskiego (Commercial utilisation of the Lublin Polesie). Acta Agrophysica 66: 219-228.

Mangerud J, Andersen ST, Berglund BE and Donner JJ, 1974. Quaternary stratigraphy of Norden, a proposal for terminology and classification. Boreas 3(3): 109-128.

Maruszczak H, 1988. Zmiany środowiska przyrodniczego kraju w czasach historycznych (Changes of natural environment in Poland in historical times). In: Michałow W and Hałoń E, eds., Przemiany środowiska gospodarczego Polski. Wrocław-Warszawa-KrakówGdańsk-Łódź, Ossolineum: 109-135

Matuszkiewicz JM, 2002. Zespoły leśne Polski (Forest associations in Poland). Warszawa, Wydawnictwo Naukowe PWN: 357pp (in Polish).

Matuszkiewicz W, 2001. Przewodnik do oznaczania zbiorowisk roślinnych Polski (Guide-book for determination of vegetation communities in Poland). In: Faliński JB, ed., Vademecum Geobotanicum 8: 1-537. Warszawa, Wydawnictwo Naukowe PWN.

Miotk-Szpiganowicz G, Zachowicz J, Ralska-Jasiewiczowa M and Nalepka D, 2004. Corylus avelana L.- Hazel. In: RalskaJasiewiczowa M, Wasylikowa K, Tobolski K, Madeyska E, Wright Jr. HE and Turner Ch, eds., Late Glacial and Holocene history of vegetation in Poland based on isopollen maps. Kraków, W Szafer Institute of Botany, Polish Academy of Sciences: 79-88.

Nowaczyk B and Tobolski K, 1981. W sprawie późnoglacjalnych osadów wapiennych akumulowanych w środowisku wodnym (Remarks on Late-Glacial limnic sediments accumulated in the water environment). Badania Fizjograficzne nad Polska Zachodnia 33: 65-78.

Paszewski A and Fijałkowski D, 1971. Badania botaniczne rezerwatu Durne Bagno koło Włodawy (summary: Botanic investigations of the Durne Bagno Reserve naer Włodawa). Annales Universitatis Mariae Curie-Skłodowska C 25: 171-196.

Perelman AJ, 1971. Geochemia krajobrazu (Geochemistry of landscape). Wrocław, Państwowe Wydawnictwo Naukowe,: 433pp (in Polish).

Polański A and Smulikowski K, 1969. Geochemia (Geochemistry). Warszawa, Wydawnictwa Geologiczne: 663pp (in Polish).

Prentice IC, Guiot J and Harrison SPJ, 1992. Mediterranean vegetation lake levels and palaeoclimate at the last glacial maximum. Nature 360: 658-660, DOI 10.1038/360658a0.

Ralska-Jasiewiczowa M, Goslar T and Bałaga K, 1999. Biostratigraphy of the Lateglacial in the lowland of Poland based on the calendar time-scale. Terra Nostra 99/10: 66-71.

Ralska-Jasiewiczowa M, Miotk-Szpiganowicz G, Zachowicz J, Latałowa $\mathrm{M}$ and Nalepka D, 2004. Carpinus betulus L. - Hornbeam. In: Ralska-Jasiewiczowa M, Wasylikowa K, Tobolski K, Madeyska E, Wright Jr. HE and Turner Ch, eds, Late Glacial and Holocene history of vegetation in Poland based on isopollen maps. Kraków, W. Szafer Institute of Botany, Polish Academy of Sciences,: 69-78.

Reimer PJ, Baillie MGL, E Bard, Bayliss A, Beck JW, Bertrand CJH, Blackwell PG, Buck CE, Burr GS, Cutler KB, Damon PE, Edwards RL, Fairbanks RG, Friedrich M, Guilderson TP, Hogg AG, Hughen KA, Kromer B, McCormac G, Manning S, Bronk Ramsey C, Reimer RW, Remmele S, Southon JR, Stuiver M, Talamo S, Taylor FW, Plicht J van der and Weyhenmeyer CE, 2004. IntCal04 terrestrial radiocarbon age calibration, 0-26 cal kyr BP, Radiocarbon, 46(3): 1029-1058.

Rzepecki P, 1985. Jeziorne osady wapienne Polski Północnej między Łyną a Brdą (summary: Lacustrine calcareous deposits of Northern Poland between Łyna and Brda rivers). Zeszyty Naukowe Akademii Górniczo-Hutniczej 11(3): 5-78.

Stockmarr J, 1971. Tablets with spores used in absolute pollen analysis Pollen et Spores 13(4): 615-625.

Szeroczyńska K, 2003. Cladoceran succession in lakes and peat bogs of Łęczna-Włodawa Lake District. Limnological Review 3: 235-242. 
Taras H, 1995. Kultura trzciniecka w międzyrzeczu Wisły, Bugu i Sanu (Trzciniecka Culture in the Vistula, Bug and San rivers interfluve) In: Gurba J, Kmieciński J, Kowalczyk J, Łopuszko T and Szczygieł R, eds., Schylek neolitu i wczesna epoka brazu w Polsce środkowowschodniej. Lubelskie Materiaty archeologiczne, VI. Lublin, Wydawnictwo Uniwersytetu Marii Curie-Skłodowskiej: 209-252 (in Polish).

Taras H, 2005. Człowiek prahistoryczny w środowisku jezior i torfowisk Pojezierza Łeczyńsko-Włodawskiego (Prehistoric man in the environment of lakes and mires of the Lęczna-Włodawa Lake District). Przewodnik II Polskiej Konferencji Paleobotaniki Czwartorzęu "Rekonstrukcja paleośrodowisk jeziornotorfowiskowych”. Okuninka (Polesie Lubelskie), 10-13 maja 2005: 58-59 (in Polish).

Tobolski K, 1991. Biostratygrafia i paleoekologia interglacjału emskiego i zlodowacenia Wisły rejonu Konińskiego (Biostratigraphy and palaeoecology of the Eemian interglacial and the Vistulian glaciation of the Konin region). In: Stankowski W, ed., Przemiany środowiska geograficznego obszaru Konin-Turek. Poznań, Uniwersytet im. Adama Mickiewicza,: 45-87.

Tobolski K, 2000. Przewodnik do oznaczania torfów $i$ osadów jeziornych (Guide-book for determination of peats and lacustrine deposits). Warszawa, Wydawnictwo Naukowe PWN: 508pp (in Polish).

Troels-Smith J, 1955. Karakterisering af lose jordarter (Charcterization of unconsolidated sediments). Danmark Geologiske Undersøgelse 4, 3(10): 39-73 (in Danish).

Tymczak D, 1998. Wczesnomezolityczne stanowisko kultury komornickiej w Wólce Wytyckiej, woj. chełmskie (Rescue Excavations at Site 50 in Wólka Wytycka, Chełm Voivodship). Archeologia Polski Środkowowschodniej 3: 9-11.
Vierling LA, 1998. Palynological Evidence for Late- and Postglacial Environmental Change in Central Colorado. Quaternary Research 49(2): 222-232, DOI 10.1006/qres.1997.1960.

Walanus A and Nalepka D, 2003. Data processing in pollen analysis. Acta Palaeobotanica 43(1): 125-134.

Warakomski W, 1998. Charakterystyka klimatyczna Pojezierza Łęczyńsko-Włodawskiego (Climatic characteristics of the ŁecznaWłodawa Lake District). In: Harasimiuk M, Michalczyk Z and Turczyński M, eds., Jeziora Łeczyńsko-Włodawskie, Monografia Przyrodnicza. Lublin, Wydawnictwo Uniwersytetu Marii CurieSkłodowskiej: 21-44 (in Polish).

Wicik B and Piotrowski W, 2002. Gleby Poleskiego Parku Narodowego (Soils of the Polesie National Park). In: Radwan S, ed., Poleski Park Narodowy. Monografia przyrodnicza. Lublin, MORPOL: 4354.

Wojciechowski I and Więckowski K, 1971. Zmiany charakteru limnologicznego jezior sosnowickich (summary: Variations in the limnological character of lakes in Sosnowica District). Wiadomości Ekologiczne 17: 239-247.

Wojciechowski A, 2000. Zmiany paleohydrologiczne w środkowej Wielkopolsce w ciągu ostatnich 12000 lat w świetle badań osadów jeziornych rynny kórnicko-zaniemyskiej (summary: Palaeohydrological changes in the Central Wielkopolska lowland during the last 12000 years on the basis of deposits of the KurnikZaniemyśl Lakes). Poznań, Wydawnictwa Naukowe Uniwersytetu im. Adama Mickiewicza: $236 \mathrm{pp}$.

Zachowicz J, Ralska-Jasiewiczowa M, Miotk-Szpiganowicz G and Nalepka D, 2004. Ulmus L.- Elm. In: Ralska-Jasiewiczowa M, Wasylikowa K, Tobolski K, Madeyska E, Wright Jr. HE and Turner Ch, eds., Late Glacial and Holocene history of vegetation in Poland based on isopollen maps. Kraków, W. Szafer Institute of Botany, Polish Academy of Sciences,: 225-235. 